\title{
Nested scales of spatial heterogeneity in juvenile walleye pollock Theragra chalcogramma in the southeastern Bering Sea
}

\author{
Kelly J. Benoit-Bird ${ }^{1, *}$, Neal E. McIntosh ${ }^{1}$, Scott A. Heppell ${ }^{2}$ \\ ${ }^{1}$ College of Earth, Ocean, and Atmospheric Sciences, and ${ }^{2}$ Department of Fisheries and Wildlife, Oregon State University, \\ 104 CEOAS Administration Building, Corvallis, Oregon 97331, USA
}

\begin{abstract}
We sought to characterize the distribution of juvenile walleye pollock Theragra chalcogramma in an area of intense predator-prey interactions and to describe habitat features that lead to their observed distributions. The distribution of juvenile walleye pollock around the Pribilof Islands in the southeastern Bering Sea in 2008 and 2009 was patchy, at spatial scales ranging from a few meters to several 10s of kilometers. These patches, and the spaces between them, were hierarchically nested with small, dense patches clustered together into larger aggregations which were further aggregated over the region sampled. Vertical physical habitat structure affected the vertical distribution of juvenile pollock similarly in both years. However, despite largely similar physical characteristics in both years, there were significant differences between years in the horizontal distribution, patch structure, and abundance of juvenile pollock. In neither year did biological or physical environment characteristics explain the broad-scale variability in the horizontal distribution of juvenile pollock, but at small horizontal scales a behavioral component was evident, with fish changing their group coherence as conditions changed despite consistent group sizes. It is clear that if we are to understand the processes that drive the distribution of juvenile pollock, we must consider multiple scales of heterogeneity. Only then will we begin to understand the role of pollock in the ecosystem and be able to predict the consequences of large sources of variability such as climate change, a critical question in the rapidly changing physical and biological environment of the Bering Sea.
\end{abstract}

KEY WORDS: Patchiness · Spatial structure $\cdot$ Walleye pollock $\cdot$ Bering Sea $\cdot$ Schooling

\section{INTRODUCTION}

Spatial heterogeneity, or patchiness, of physical characteristics and organisms is a common phenomenon in the ocean (Steele 1978). Significant spatial variations in oceanic biomass, e.g. patches, have been observed at scales of centimeters (Dekshenieks et al. 2001) to hundreds of kilometers (Mackas et al. 1985), often with smaller scale patches nested hierarchically within larger patches (Wu \& Loucks 1995). These patterns can affect community organization and stability, population dynamics, and trophic inter- actions (see a review in Levin 1992). Thus, understanding the development and persistence of spatial and temporal patterns and the consequences of those patterns for the dynamics of populations and ecosystems are fundamental themes in ecology (Hunter \& Price 1992).

Walleye pollock Theragra chalcogramma is a generally demersal fish species native to the North Pacific Ocean. Juvenile walleye pollock are an important trophic link in the Bering Sea ecosystem. Young-of-the-year (Age-0) pollock primarily prey on small zooplankton such as copepods and, at larger 
sizes, euphausiids (Brodeur 1998). In turn, juvenile pollock are prey for a variety of demersal fish species, especially adult walleye pollock, sea birds such as common and thick-billed murres, and marine mammals such as northern fur seals Callorhinus ursinus (Livingston 1993). At Age 3, walleye pollock recruit to the largest commercial fishery in the United States (Livingston 1993).

Spatial distributions of pollock are highly variable at scales ranging from tens of meters (Swartzman et al. 1999a) to hundreds of kilometers (Ressler et al. 2012), likely a result of a combination of biological and physical factors such as growth potential, prey availability, advection, and predator avoidance (Bailey 1989, Ciannelli 2002). At the largest scales, the distribution of young-of-the-year pollock is affected by the spawning patterns in adult fish (Bacheler et al. 2012), as well as the survival and recruitment of the resulting offspring (Bailey et al. 2005). At scales of kilometers, patchiness of youngof-the-year pollock is likely driven largely by advection, including regional circulation and more localized ocean frontal patterns (Schabetsberger et al. 2003) because of the limited swimming capacity (Ryer \& Olla 1997) of these small fish. At smaller scales, juvenile pollock distributions are related to intrinsic factors like hunger and stress, physical factors including light and turbulence, and biotic factors including social interactions and prey (Bailey 1989, Olla et al. 1995). The horizontal distribution of juvenile pollock at all spatial scales has been linked both directly (Swartzman et al. 1994, Smart et al. 2012) and indirectly to temperature (Hunt et al. 2011, Smart et al. 2012), which can serve as a proxy for physical features like oceanographic fronts. Temperature may help regulate the metabolism and mortality of juvenile pollock (Smart et al. 2012), and has been identified as a driver in overall population dynamics (Hunt et al. 2002, 2011), which could account for the vertical coupling observed between fish and the thermocline (Bailey 1989, Swartzman et al. 1999b).

The distributions of prey (Bailey 1989), competitors (Ressler et al. 2012), and predators (Ryer \& Olla 1998) affect spatial patterns in juvenile pollock. These factors can lead to differential growth and survival, resulting in heterogeneous distributions of individuals (Napp et al. 2000). Studies at small scales (e.g. tens of meters) have shown that behavior also plays an important role in determining the spatial influences of these sources of environmental variability on walleye pollock (Sogard \& Olla 1993, Olla et al. 1996). For example, juvenile walleye pollock use 'group foraging' when searching for prey that is patchy, leading to aggregations of conspecifics (Ryer \& Olla 1995). Laboratory experiments show that these aggregations of pollock, which may be coordinated and polarized and thus be termed schools, can also be affected by light, temperature, predators, hunger, and social factors (Olla et al. 1996, Ryer \& Olla 1998). Studies have identified similar, smallscale aggregations of juvenile pollock in the Bering Sea, providing evidence that behavioral attraction occurs under natural conditions (Swartzman et al. 1994, 1999a). Vertical migrations of 20 to $60 \mathrm{~m}$ in extent, depending on individual body length (Brodeur \& Wilson 1996, Schabetsberger et al. 2000), provide additional evidence of the role of behavior in driving in situ distributions despite the limited abilities of juvenile pollock to overcome currents (Ryer \& Olla 1997).

The objective of this study was to characterize the spatial heterogeneity of juvenile walleye pollock over spatial scales on the order of $10^{0.5}$ to $10^{5} \mathrm{~m}$. From the outset, we postulated that aggregations at one scale could be nested in aggregations at larger scales. Therefore, we looked at the smallest resolvable scale all the way up to regional differences, rather than focusing exclusively on one scale, e.g. schools (Swartzman et al. 1994, 1999a) or broad-scale distributions (e.g. Ressler et al. 2012). Our second objective was to understand how the spatial heterogeneity of juvenile pollock was affected by the physical and biological environmental drivers across scales, both vertically and horizontally.

This work was conducted as one element in a larger, interdisciplinary program known as the Bering Sea Project (Wiese et al. 2012). In part, this program was designed to understand how the population dynamics and behavior of marine birds and fur seals breeding on the Pribilof Islands are driven by the availability and quality of the forage base surrounding their breeding colonies. Accessibility to juvenile pollock as a prey source has been shown to have a strong impact on the reproductive success of these predators (Zeppelin \& Ream 2006, Renner et al. 2012). Embedded in our overall approach was the goal of identifying pollock spatial heterogeneity over the range of scales at which these predators forage. To examine juvenile pollock and their habitat, we used short, closely spaced transects stratified across different bathymetrically defined zones radiating around the Pribilof Islands, an area of intense interactions between juvenile pollock, their prey, and their predators (Swartzman et al. 1999a, Swartzman \& Hunt 2000). 


\section{METHODS}

\section{Study site}

The Pribilof Islands are an archipelago on the edge of the Bering Sea shelf, west of mainland Alaska and north of the Aleutian Island chain. The 2 largest islands, St. Paul and St. George, are located approximately $90 \mathrm{~km}$ apart, and make up $97 \%$ of the landmass of the archipelago. There is a tidally driven front separating the well-mixed water close to each island from the highly stratified waters of the Bering Sea shelf (Kinder et al. 1983, Stabeno et al. 1999). The islands and the surrounding waters are highly productive, and serve as a nursery area for juvenile walleye pollock Theragra chalcogramma (Swartzman et al. 1999b). During the summer, the islands harbor some of the largest seabird colonies in the Northern Hemisphere (Hickey \& Craighead 1977), and have northern fur seal Callorhinus ursinus rookeries that account for nearly 3 quarters of the worldwide population (Angliss \& Lodge 2004). The high abundance of juvenile pollock predators breeding on the Pribilof Islands and the highly productive, heterogeneous habitat in the nearby waters make it an ideal place to study the small-scale distributions of Age-0 walleye pollock.

\section{Field data}

We sampled a series of $10 \mathrm{~km}$ transects in the area surrounding the Pribilof Islands aboard chartered fishing vessels from mid-July to mid-August of 2008 and 2009. Each transect consisted of a conductivity, temperature and depth (CTD) cast at the start of the transect, to measure oceanographic characteristics, a vertical net tow for mesozooplankton, a targeted trawl for euphausiids and forage fish, $10 \mathrm{~km}$ of multi-frequency acoustics to estimate euphausiid and fish biomass and distribution, and a second CTD cast at the end of the transect. Sampling of each transect took approximately $90 \mathrm{~min}$ to complete. Transects were conducted throughout the day and night, though no sampling was con- ducted during crepuscular periods (defined as the hour surrounding sunset and sunrise).

In 2008, 110 transects were surveyed from the FV 'Frosti' between 13 July and 7 August. In 2009, 72 transects were completed with duties split between the FV 'Frosti' and the FV 'Gold Rush' between 18 July and 12 August (Fig. 1). During both years, 65 transects were planned pre-cruise, 60 were distributed randomly within 3 bathymetrically defined zones within $200 \mathrm{~km}$ of St. Paul, Alaska $\left(57^{\circ} 08^{\prime} 05^{\prime \prime} \mathrm{N}, 170^{\circ} 19^{\prime} 34^{\prime \prime} \mathrm{W}\right)$ and 5 were distributed around the 2 largest of the Pribilof Islands. Zones were determined by depth following previous studies in this area; the Middle Shelf Zone (MS) had depths from 50 to $100 \mathrm{~m}$; the Outer Shelf Zone (OS), from 100 to $200 \mathrm{~m}$; and the Slope Zone (SL), > $200 \mathrm{~m}$ (Coachman 1986). Three of the 20 planned transects within each zone were designated as repeat transects and were visited multiple times throughout the
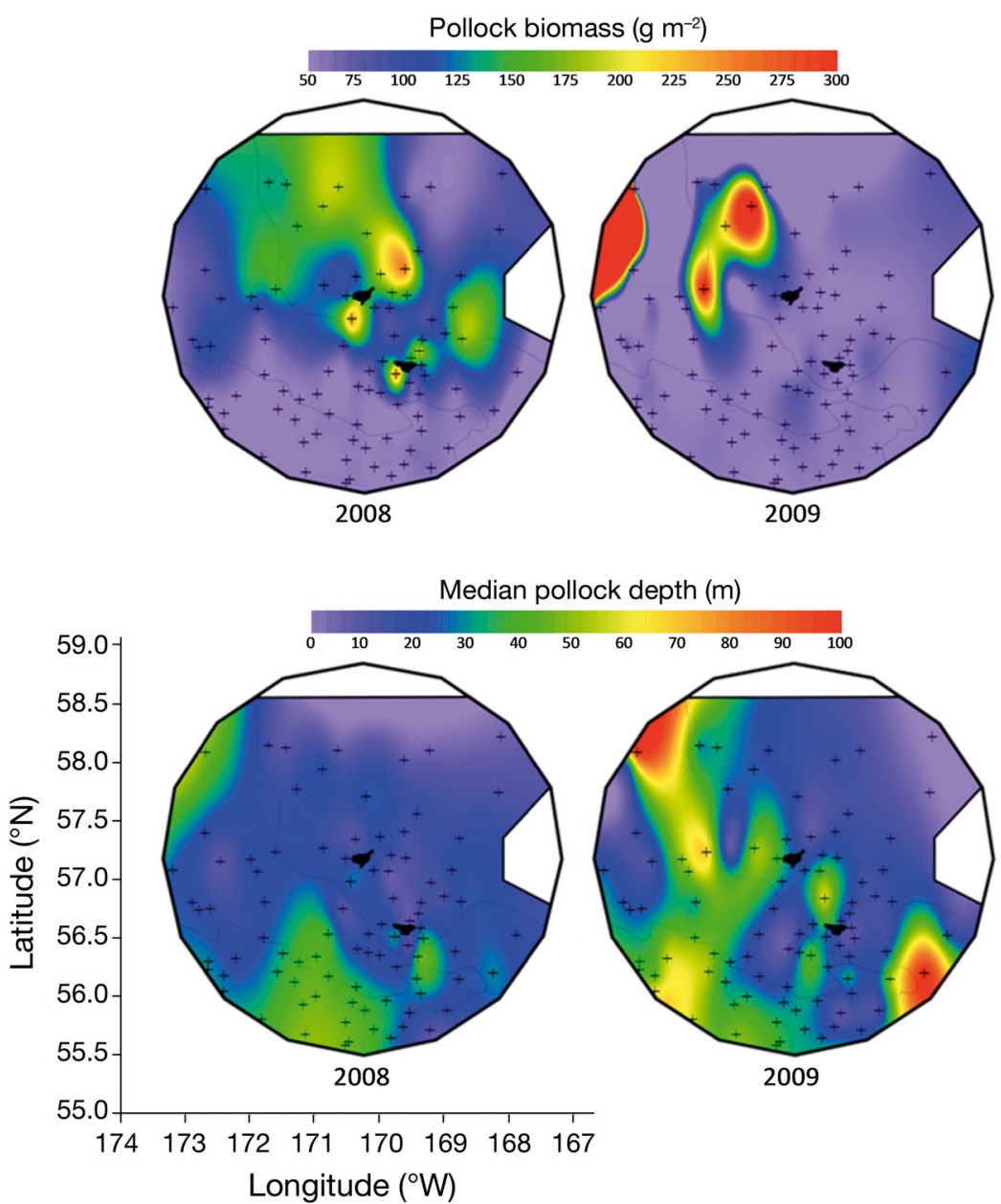

Fig. 1. Theragra chalcogramma. Horizontal (top panels) and vertical (bottom panels) distributions of juvenile walleye pollock around the Pribilof Islands in each study year. A black cross indicates the midpoint of each $10 \mathrm{~km}$ transect. White areas did not have enough data for inclusion in the plotted surface 
cruise. Additional 'adaptive' transects were added on an ad hoc basis during the cruise based on several criteria, including: large patches of fish or euphausiids observed using acoustics, large aggregations of feeding birds or mammals seen on the water, or telemetry-tagged birds or mammals found in the vicinity of vessel surveys, as reported to us in real time from other ongoing studies.

Multi-frequency acoustic data were collected using Simrad EK60 split-beam echosounders along all transects, and most of the time the vessels were in transit through the study area. Transducers were affixed approximately $1 \mathrm{~m}$ below the surface to a rigid pole mount attached to the side of the vessel. Vessel speed for acoustic surveys was approximately $9.3 \mathrm{~km} \mathrm{~h}^{-1}$. Acoustic frequencies used were 38, 70, 120, and $200 \mathrm{kHz}$. The $38 \mathrm{kHz}$ system had a conical beam angle of $12^{\circ}$; each of the 70,120 , and $200 \mathrm{kHz}$ systems had a conical beam angle of $7^{\circ}$. The pulse length for all frequencies was $256 \mu$ s. Echosounders were calibrated, following the method described by Foote et al. (1987), with a $38.1 \mathrm{~mm}$ diameter tungsten carbide reference sphere. The $38 \mathrm{kHz}$ echosounder had an effective range of $1200 \mathrm{~m}$, while the 70, 120, and $200 \mathrm{kHz}$ echosounders had ranges of 600,350 , and $200 \mathrm{~m}$, respectively. Acoustical echograms of the 4 frequencies were viewed in real time so that the abundance and distribution of biological scatterers could guide in situ sampling.

A Sea Bird Electronics CTD sensor package was used to profile water characteristics to a depth of $100 \mathrm{~m}$ or $10 \mathrm{~m}$ above the bottom, whichever was shallower, at the beginning and end of each transect. In addition to conductivity, temperature, and pressure, the CTD unit measured dissolved oxygen, fluorescence, and light transmission at $530 \mathrm{~nm}$. In 2008 the FV 'Frosti' used a SBE 19 V.1 CTD with a Wet Labs ECO-FLNTURT combination fluorometer-turbidity sensor, a CSTAR green light transmissometer, and a Sea Bird Electronics 42 dissolved oxygen sensor. In 2009 the FV 'Gold Rush' used the same CTD package that was used on the FV 'Frosti' in 2008. In 2009 the FV 'Frosti' used a SBE 19 V.2 CTD with a Wet Labs Wet Star fluorometer, a CSTAR green light transmissometer, and a Sea Bird Electronics $42 \mathrm{O}_{2}$ sensor. Both CTDs were equipped with a remote depth sensor (Simrad PI32) that allowed the depth of the package to be observed in real time.

A vertically integrated zooplankton net tow was performed at the beginning of each transect to a depth of 100 or $10 \mathrm{~m}$ above the bottom, whichever was shallower. The net was kept as close to vertical as weather conditions would allow. Net depth was guided by a real-time remote depth sensor (Simrad PI32) affixed to the net. The zooplankton net had a $0.75 \mathrm{~m}$ diameter mouth, $333 \mu \mathrm{m}$ mesh, and was equipped with a General Oceanics flowmeter modified to only operate on the upward portion of the cast. The net was towed at a rate of $1 \mathrm{~m} \mathrm{~s}^{-1}$, and zooplankton captured in the net were immediately preserved in a solution of $5 \%$ buffered formalin in seawater for later analyses.

Following the zooplankton net tow, a 20 min targeted trawl for fish and euphausiids was performed at a vessel speed of approximately 2 to $4 \mathrm{~km} \mathrm{~h}^{-1}$ using a modified Marinovich trawl. The net measured $10.5 \mathrm{~m}$ in length, with a $49 \mathrm{~m}^{2}$ square opening, and with a cod end liner with $3 \mathrm{~mm}$ mesh. Acoustic data were used to target the trawl at a depth within the upper $100 \mathrm{~m}$ of the water column where the net would be most likely to encounter aggregations of fish or euphausiids. This depth range covered $>95 \%$ of the acoustic scattering attributed to pollock and $90 \%$ of that attributed to krill. Real-time remote sensors placed at the mouth of the net were used to monitor net depth, as well as vertical and horizontal spread. Immediately after capture, non-jellyfish contents of the net were identified, enumerated, and 20 randomly selected individuals of each species were measured for length before subsamples were frozen for further analysis.

\section{Data analysis \\ CTDs}

Using custom routines, all CTD data were aligned to account for instrument lags, data were filtered, edited for loops, and low-pass filtered before calibrations were applied to convert data to appropriate measures. Clines (e.g. thermocline, oxycline) were determined by finding the largest point-to-point difference in $0.5 \mathrm{~m}$ averaged downcast values and visually compared to profiles for validation. Water column stratification $\left(\mathrm{d}_{\mathrm{t}} \mathrm{dz}^{-1}\right)$ was calculated by taking the difference in the densities at $1 \mathrm{~m}$ below the surface and at the deepest point of the cast and dividing by the depth of the cast.

\section{Zooplankton}

Zooplankton preserved wet weights were determined in the laboratory post-cruise. Each sample was washed with a solution of $5 \%$ buffered formalin 
and seawater onto a $15 \mathrm{~cm}$ diameter, $5 \mu \mathrm{m}$ particle retention filter paper under low levels of vacuum pressure until excess fluid was removed. If samples were $>\sim 500 \mathrm{ml}$, a Folsom plankton splitter was used to create a subsample prior to filtering. This procedure was then used to filter blank samples of $5 \%$ buffered formalin and seawater to determine the average weight of an empty wet filter; 4 volumes each of 100,200,300,400, and $500 \mathrm{ml}$ were filtered. The empty filter weights were not significantly different and did not vary with volume of fluid filtered. After samples were free of excess water, the contents of the filter were weighed on an analytical scale to the nearest $0.001 \mathrm{~g}$ with the average wet filter weight subtracted to yield the sample wet weight. To convert to biomass density, wet weights were divided by the volume of water sampled by the zooplankton net.

Ten samples from the Outer Shelf Zone were selected from the 2009 zooplankton samples for further analysis. These samples were split with a Folsom plankton splitter and examined under a dissection microscope; zooplankton were identified to the lowest taxonomic group possible (copepods were identified to genus), enumerated, and a random subsample of each identified group was measured for length. Zooplankton were measured in a fraction of the sample that yielded a count of $\geq 100$ ind. per identified group. If there were $<100$ ind. of that group, the entire sample was counted and every individual measured. For statistical analyses, zooplankton were classified by size into the following groups: $<2,2$ to 4 , 4 to 6 , and $>6 \mathrm{~mm}$ for all zooplankton classes; for additional analysis, copepods were grouped as small if prosome length was $<2 \mathrm{~mm}$ and large if prosome length was $>2 \mathrm{~mm}$.

\section{Acoustic data}

Acoustic data were analyzed using Echoview Version 4.7 (Myriax). Volume scattering was averaged over cells of $5 \mathrm{~m}$ depth and 5 echoes wide from $5 \mathrm{~m}$ below the surface to $0.5 \mathrm{~m}$ from the bottom or to $100 \mathrm{~m}$ depth, whichever was shallower. The binned volume scattering at $38 \mathrm{kHz}$ was subtracted from that at $120 \mathrm{kHz}$ to categorize data as either swimbladdered fish or euphausiids based on the observed frequency response (Kang et al. 2002, Korneliussen \& Ona 2002). Cells designated as 'fish' had a $S_{\mathrm{v} 120}$ to $\mathrm{S}_{\mathrm{v} 38}$ in the range of -9.3 to $9.3 \mathrm{~dB}$; cells categorized as 'euphausiids' were within the range of 9.3 to $30 \mathrm{~dB}$ (De Robertis 2010).
The integrated scattering (nautical area scattering coefficient [NASC], in square meters per square nautical mile $\left.\left[\mathrm{m}^{2} \mathrm{nmi}^{-2}\right]\right)$ was calculated over the entire transect to a depth of $100 \mathrm{~m}$ using a $-85 \mathrm{~dB} \mathrm{~S}_{\mathrm{v}}$ integration threshold for each category; 'fish' were integrated at $38 \mathrm{kHz}$ and 'euphausiids' were integrated at $120 \mathrm{kHz}$. When the acoustical layers targeted with the trawl were identified as 'fish', the trawls were overwhelmingly dominated $(>95 \%$ of the entire catch, including jellyfish and other invertebrates) by numbers and biomass - by juvenile walleye pollock. Other schooling species known to be found in the Bering Sea, including capelin and sand lance, were absent from all trawls. In both years most of the juvenile walleye pollock caught were a size (<66 mm) consistent with Age-0 pollock. In 2008, a few individual Age-1 pollock were caught on one transect ( $<1 \%$ of total transects), and, in 2009, Age-1 or older pollock were caught on 3 of the planned transects $(<5 \%$ of total transects). Thus, scattering consistent with fish can be interpreted as scattering from juvenile walleye pollock. Comparisons of area scattering over the volume sampled by individual net tows and the estimated biomass of pollock and euphausiids in the net tows had significant relationships for 'fish' sampled at $38 \mathrm{kHz}\left(\mathrm{R}^{2}=0.74, \mathrm{p}<0.05\right)$ and 'euphausiids' sampled at $120 \mathrm{kHz}\left(\mathrm{R}^{2}=0.57, \mathrm{p}<\right.$ $0.05)$, suggesting that these acoustic measures can be used as proxies for euphausiid and fish abundances (Benoit-Bird et al. 2011). For presentation of data, scattering from fish was converted to biomass density using the target- strength biomass relationship for walleye pollock (Williamson \& Traynor 1996).

Juvenile pollock were observed in echograms to be highly spatially aggregated. To isolate largescale aggregations (layers), Myriax's Echoview Software, School Detection module was used on the 'fish' masked, full-resolution $38 \mathrm{kHz}$ echograms to a depth of $200 \mathrm{~m}$. Simply, this approach looks for a minimum number of contiguous values above a set threshold in both the distance and depth directions (Barange 1994). To be classified as an aggregation, pollock acoustic density had to exceed $-65 \mathrm{~dB}$ re $1 \mathrm{~m}^{-1}$, equivalent to 0.1 fish $\mathrm{m}^{-3}$ for median-sized Age-0 pollock, for at least $5 \mathrm{~m}$ vertically and $5 \mathrm{~m}$ along-track as corrected for beam effects (Diner 2001) and could not be separated from potential candidate pixels $>1 \mathrm{~m}$ in size by $>2 \mathrm{~m}$ horizontally or with depth. Results of the school detection analysis were visually scrutinized and corrected for artifacts due to noise or instrument drop outs, as appropriate. The resulting aggregations encompassed $>97 \%$ of pixels classified as 'fish'. 
The minimum, maximum, and median pollock depths for each transect were determined using juvenile pollock layers. The pollock median depth was defined as the depth at which $50 \%$ of the scattering from pollock observed on that transect was evenly divided in the water column. The depth interval inhabited by Age- 0 pollock was determined by subtracting the minimum pollock depth from the maximum pollock depth. The difference between thermocline depth and median pollock depth was used to assess Age-0 pollock vertical distribution in relation to the thermocline.

Visual analysis showed that pollock spatial aggregations were hierarchically distributed with dense, ovoid patches inside larger, more loosely aggregated layers (Fig. 2). To isolate these patches within layers, school detection was repeated with the same spatial settings in $3 \mathrm{~dB}$ re $1 \mathrm{~m}^{-1}$ steps until no pollock were detected. At thresholds between -62 and $-53 \mathrm{~dB}$ re $1 \mathrm{~m}^{-1}$ there were no significant changes in the mean volume scattering strength measured within each patch or the horizontal and vertical size of each patch despite changes in the number of patches detected, indicating the high contrast between these patches and the remainder of pollock. For further analyses, a threshold of $-59 \mathrm{~dB}$ re $1 \mathrm{~m}^{-1}$, approximately 0.5 fish $\mathrm{m}^{-3}$ for Age- 0 fish, was chosen to maximize the number of transects with detected patches. Our $-59 \mathrm{~dB}$ threshold is close to the $-60 \mathrm{~dB}$ threshold suggested

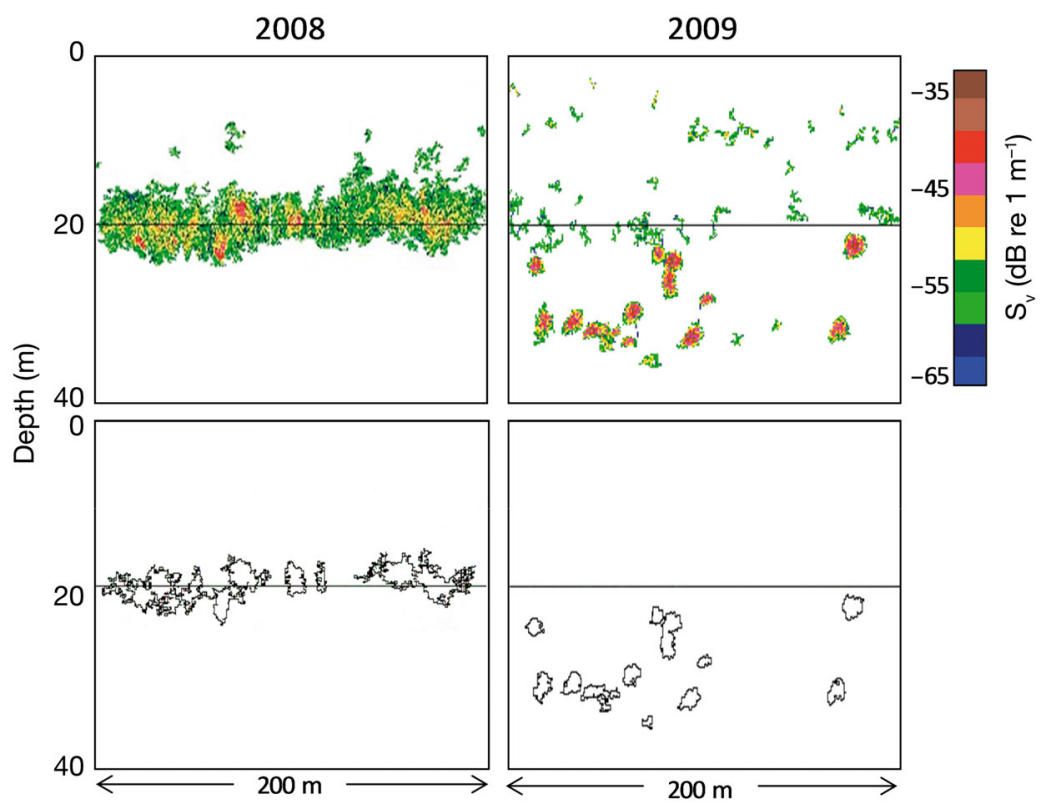

Fig. 2. Theragra chalcogramma. Representative echograms of layers of juvenile pollock detected at 0.1 fish $\mathrm{m}^{-3}$ (top panels), and corresponding outlines of juvenile pollock patches (lower panels) detected at $0.5 \mathrm{fish} \mathrm{m}^{-3}$, in 2008 (left panels) and 2009 (right panels) by previous studies as being a conservative enough threshold to isolate juvenile walleye pollock in schools from other scatterers (Burgos \& Horne 2007).

Pollock patches were clustered in many echograms. The distribution of inter-pollock patch spacing was bimodal, with a break between the modes at approximately $100 \mathrm{~m}$. To identify these larger scale aggregations of pollock, we grouped together all patches found $<100 \mathrm{~m}$ from neighboring patches. The horizontal size of each cluster of patches and the spacing between these clusters along a transect were measured.

\section{Statistical analyses}

All statistical analyses were performed using data collected at the transect scale. To analyze the effects of environmental variation on juvenile pollock distribution, best subsets multiple linear regression model selections were performed using a randomly selected $50 \%$ subset of the 2008 transects with acoustically identified pollock. For the vertical distribution of layers of Age-0 pollock the response variable was median pollock depth. Possible explanatory variables for the vertical distribution were: bathymetric zone; time of day; thermocline depth; mean temperature above and below the thermocline; temperature at pollock minimum, maximum, and median depth; mean standard length of pollock; water column stratification; oxycline depth; and chlorophyll maximum depth. For the horizontal distribution of layers of juvenile pollock, the response variable was the $38 \mathrm{kHz}$ NASC value, and possible explanatory variables were: bathymetric zone, time of day, day of the year, surface temperature, thermocline depth, mean temperature to $100 \mathrm{~m}$ depth, surface salinity, total chlorophyll concentration integrated over the upper $100 \mathrm{~m}$, maximum chlorophyll concentration within the upper $100 \mathrm{~m}$, oxycline depth, minimum oxygen saturation, water column stratification, euphausiid abundance (120 kHz NASC), zooplankton total biomass, and distance from nearest predator breeding colony. The model selection procedure was repeated on a randomly selected $50 \%$ subset of the 2009 transects with acoustically identified pollock and a randomly selected $50 \%$ subset of the combined 2008/2009 
transects with acoustically identified pollock. The best models were selected using a combination of 2 methods: (1) the models with the highest adjusted $\mathrm{R}^{2}$ and (2) a Cp statistic, an estimate of the total mean square prediction error, less than or equal to the number of parameters in the model were chosen

Once the best models were identified using the adjusted $\mathrm{R}^{2}$ and $\mathrm{Cp}$ method, they were run on all of the 2008 transects with acoustically identified pollock, all of the 2009 transects with acoustically identified pollock, and on the combined data set. The best models were also used to evaluate the horizontal and vertical distribution of pollock patches. The response variable for the vertical distribution of pollock patches was the mean depth of patches by transect. The response variable for the horizontal distribution of pollock patches was the proportion of biomass within patches multiplied by the $38 \mathrm{kHz}$ NASC value for the transect. Since several of the adaptive transects were placed in response to the detection of large aggregations of fish, as indicated by acoustics output, the analysis of the horizontal distribution of Age-0 pollock was performed only on planned transects with acoustically identified pollock.

Analysis of variance (ANOVA) was used to compare differences in the environmental variables used in the horizontal and vertical model selections between sample years and zones. Paired $t$-tests were used to compare inter-annual differences in the environmental variables for transects that were repeated in both 2008 and 2009. ANOVA was also used to compare differences in juvenile pollock distributions between years, among zones, and to make day versus night comparisons. Tukey's honestly significant difference (Tukey's HSD) tests were performed on a post hoc basis on significant ANOVA results, and $95 \% \mathrm{CI}$ around the difference in the means were determined.

In 2009, juvenile pollock abundances within the Outer Shelf Zone were highly variable. Within this zone 5 transect pairs were selected to include 1 transect with a high abundance of acoustically identified juvenile pollock (38 $\mathrm{kHz}$ NASC $>150 \mathrm{~m}^{2} \mathrm{nmi}^{-2}$ ) and 1 transect with a low abundance of pollock $(38 \mathrm{kHz}$ NASC $<50 \mathrm{~m}^{2} \mathrm{nmi}^{-2}$ ). Transects chosen for paired analysis were geographically close, were sampled within a few days of each other, and were sampled at a similar time of day or night. Paired $t$-tests were performed to determine whether differences in oceanographic parameters might account for the difference in pollock abundance. There were no significant differences in oceanographic parameters between the pairs, so these samples were deemed appropriate to use as paired samples to compare transects with high and low abundance of Age-0 pollock in terms of zooplankton community structure. To determine if Age-0 pollock distribution was related to zooplankton community structure, multiple analysis of variance (MANOVA) and paired $t$-tests were performed on species composition, zooplankton and copepod size classes, and species diversity and evenness indices from these samples using a factor classification for high or low Age-0 pollock abundance and taking into account the paired nature of the samples.

\section{RESULTS}

Physical measures of the environment were similar between the 2 sample years, but were different across zones, while measures of chlorophyll concentration and vertical distribution of chlorophyll varied by year, but showed little effect of zone (Table 1).

Walleye pollock Theragra chalcogramma caught in the trawls had a mean standard length of $41.4 \mathrm{~mm}$, with an SD of $41.5 \mathrm{~mm}$. The frequency distribution of sampled pollock lengths (Fig. 3) was bimodal, with the strongest peak at $35 \mathrm{~mm}$ and a secondary distribution centered around $130 \mathrm{~mm}$. No pollock were observed to have a standard length between 67 and $91 \mathrm{~mm}$, similar to previous studies (Nishimura \& Yamada 1988, Brown \& Bailey 1992), indicating a break in cohorts which we used to define Age-0 and Age-1 pollock. Age-0 pollock caught in the trawls varied by year (2008 mean: $36.8 \mathrm{~mm}$; 2009 mean: $20.3 \mathrm{~mm}$ ) and by zone (MS mean: 35.9; OS mean: 45.1; SL mean $33.3 \mathrm{~mm}$ ), with significant interaction between year and zone (ANOVA, p < 0.01). Age-0 pollock caught in the trawls were significantly larger in 2009 than in 2008, after accounting for zone $(95 \%$ Tukey's HSD CI of 5.93 to $9.70 \mathrm{~mm}, \mathrm{p}<0.00001$; ANOVA, $\mathrm{p}<0.00001$; $95 \%$ paired $t$-test $\mathrm{CI}$ of 5.52 to $9.42 \mathrm{~mm}, \mathrm{p}<0.0001$; Fig. 3). After accounting for year, Age-0 pollock were significantly larger over the Outer Shelf than over the Middle Shelf (95\% Tukey's HSD CI of 3.22 to $8.33 \mathrm{~mm}, \mathrm{p}<0.00001$; ANOVA, p $<0.00001$ ), and significantly larger in the Slope Zone than in the Middle Shelf Zone (95\% Tukey's HSD CI of 0.69 to $6.66 \mathrm{~mm}, \mathrm{p}<0.05)$, but there was no significant difference in length between pollock from the Outer Shelf and the Slope (Tukey's HSD, p > 0.05). After removing the 2008 Middle Shelf data, the year effect was still significant (ANOVA, p < 0.05), but the zone effects were no longer significant (ANOVA, p > 0.05). 


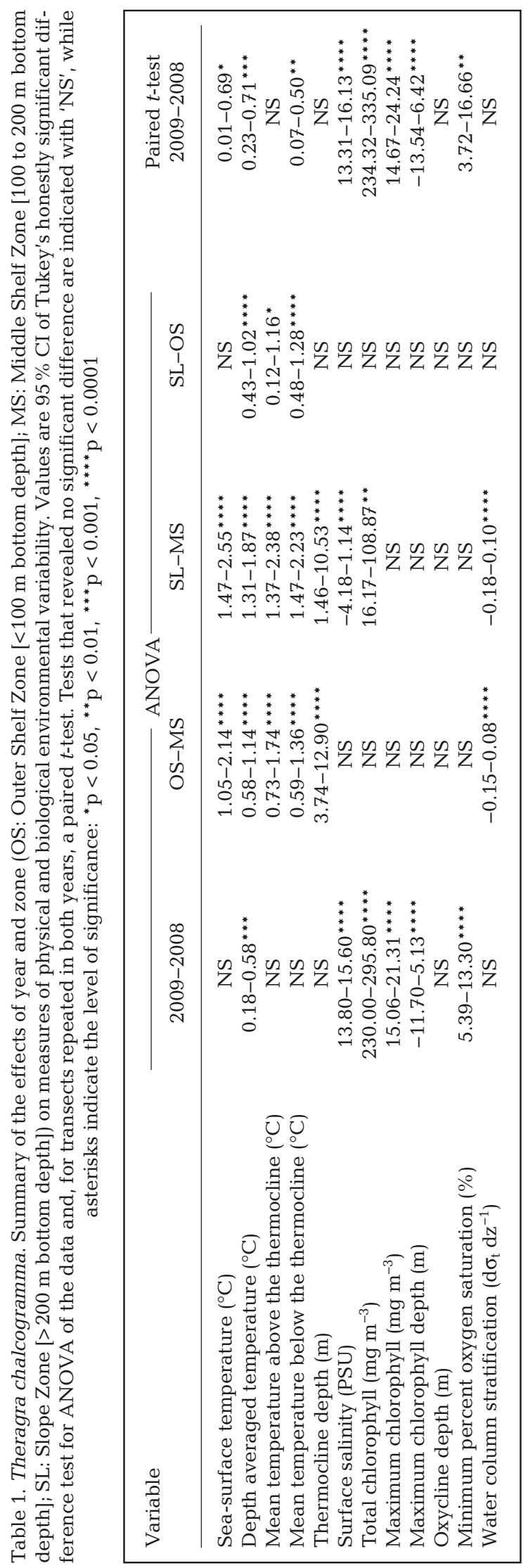

\section{Pollock horizontal distribution}

The acoustically determined biomass of Age-0 pollock varied significantly by year (2008 mean: $67.0 \mathrm{~g}$ pollock $\mathrm{m}^{-2}$; 2009 mean: $20.3 \mathrm{~g}$ pollock $\mathrm{m}^{-2}$ ) and by zone (MS mean: $66.4 \mathrm{~g}$ pollock ${ }^{-2}$; OS mean: $41.2 \mathrm{~g}$ pollock $\mathrm{m}^{-2}$; SL mean: $3.2 \mathrm{~g}$ pollock $\mathrm{m}^{-2}$ ), with a significant interaction between zone and year (ANOVA, $\mathrm{p}<0.0001$; Fig. 4). Age-0 pollock biomass was significantly higher in 2008 than in 2009 after accounting for zone $(95 \%$ Tukey's HSD CI of 0.20 to $0.45 \mathrm{~g}$ pollock $\mathrm{m}^{-2}, \mathrm{p}<0.0001$; ANOVA, $\mathrm{p}<0.0001$; Fig. 4). Age- 0 pollock biomass was significantly greater in the Middle Shelf Zone than in the Outer Shelf Zone

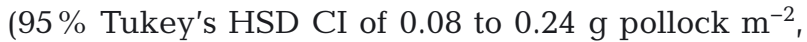
$\mathrm{p}<0.05)$, in the Middle Shelf Zone than in the Slope Zone ( $3.2 \mathrm{~g}$ pollock m $\left.^{-2}\right)(95 \%$ Tukey's HSD CI of 0.38

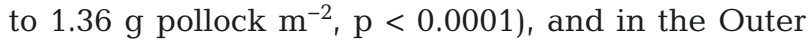
Shelf than in the Slope (95\% Tukey's HSD CI of 0.20 to $0.75 \mathrm{~g}$ pollock $\mathrm{m}^{-2}, \mathrm{p}<0.0001$ ).

Age-0 pollock were more widely distributed in 2009 than in 2008 (Fig. 1). Acoustically identified pollock were found in 39 of the 62 random, nonrepeated transects $(63 \%)$ in 2008 and in 47 of the 54 random, non-repeated transects $(87 \%)$ in 2009. No significant relationship was found between juvenile pollock biomass and any of the explanatory variables used in the multiple linear regression model (MLR) selection.

Mesozooplankton biomass (wet weight) ranged from 0.02 to $14.49 \mathrm{~g} \mathrm{~m}^{-3}$ across all transects sampled. The mean biomass of mesozooplankton was significantly higher in 2009 than in 2008 (2.78 vs. $1.14 \mathrm{~g}$ $\mathrm{m}^{-3} ; 95 \%$ CI of 0.95 to $2.40 \mathrm{~g} \mathrm{~m}^{-3}$, ANOVA, $\mathrm{p}<$ $0.0001 ; t$-test, $\mathrm{p}<0.0001 ; 95 \%$ paired $t$-test $\mathrm{CI}$ of 0.85 to $\left.1.29 \mathrm{~g} \mathrm{~m}^{-3}, \mathrm{p}<0.0001\right)$. There was no significant relationship between total mesozooplankton biomass and the horizontal distribution of Age-0 pollock (simple linear regression [SLR], $p>0.05$ ), nor was there a significant relationship between acoustically determined euphausiid abundance (120 kHz NASC) and the abundance of acoustically identified Age-0 pollock (38 kHz NASC) for the planned transects (SLR, $p>0.05)$. Since no relationships were found between pollock and krill, further analyses of krill are not presented here, but can be found in Benoit-Bird et al. (2011).

Examination of the species composition of mesozooplankton revealed that isopods and large copepods $(>2 \mathrm{~mm}$ ) were the only taxa that had significantly different abundances on transects with low acoustically determined pollock abundance than on those with a high abundance of pollock. The mean 


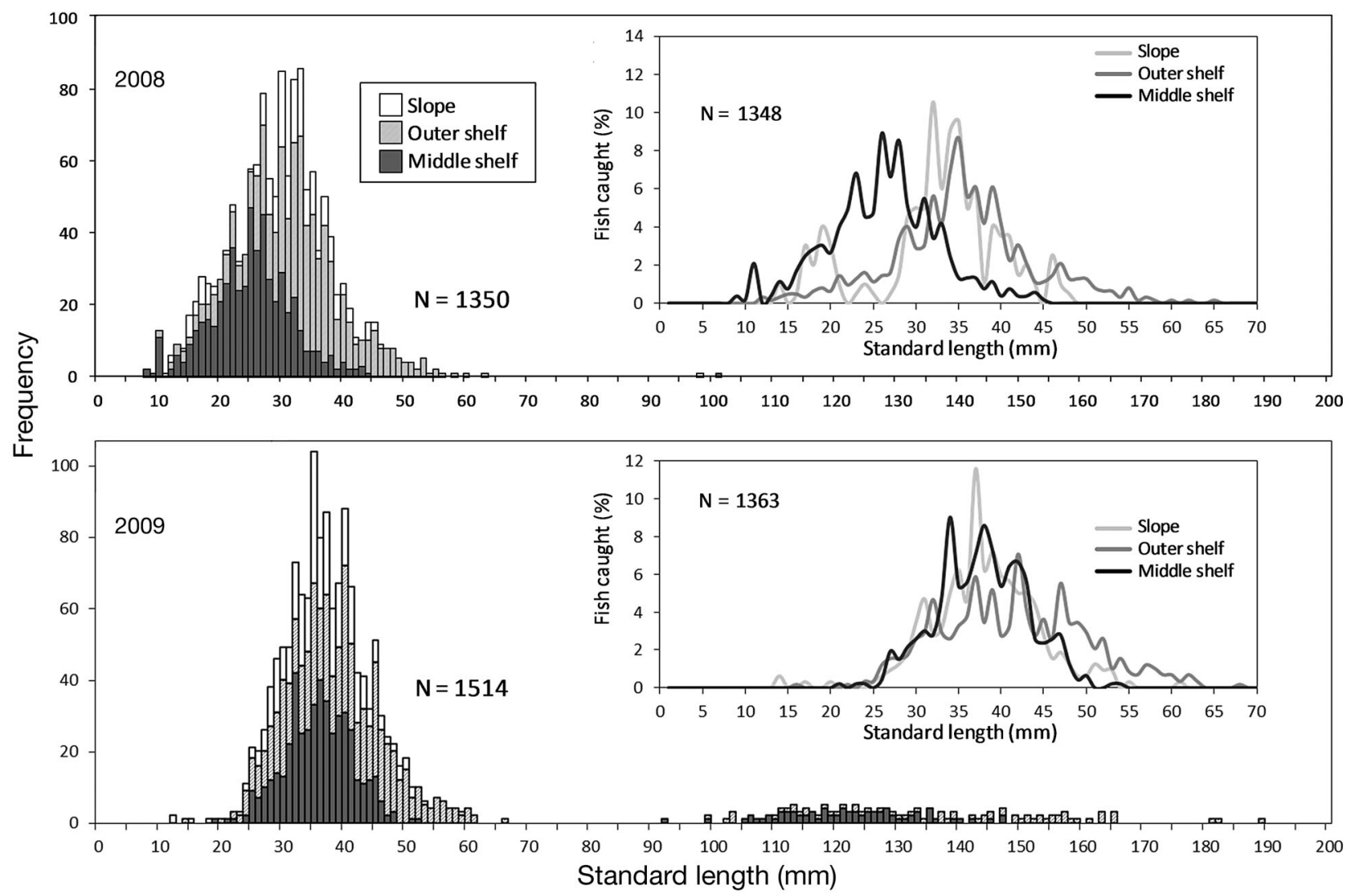

Fig. 3. Theragra chalcogramma. Stacked length-frequency distributions by zone of all walleye pollock measured from trawls in 2008 (top panel) and 2009 (bottom panel), with standard length (SL) < $200 \mathrm{~mm}$. Pollock with SL > $200 \mathrm{~mm}$ are not shown (2008: $N=1 ; 2009: \mathrm{N}=27$ ). Insets show the percent of fish caught of each size in each zone for Age-0 walleye pollock (SL < $70 \mathrm{~mm}$ ). There were no differences in sampling dates between years and no significant relationships between day of the year and length in either year. Based on this and consistent patterns in energy density with size across years, Whitman (2010) sug-

gested that differences in hatch date were the most likely cause of the inter-annual differences in pollock size observed

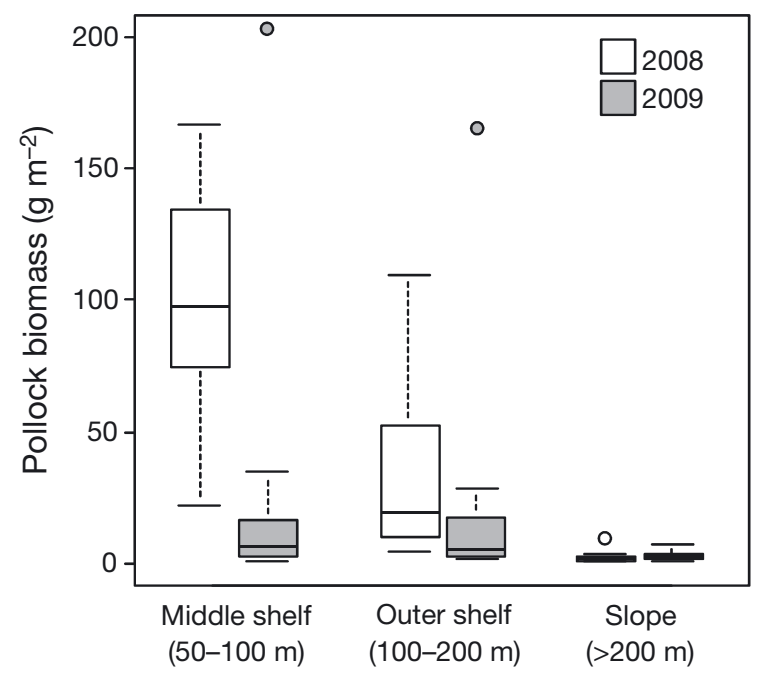

Fig. 4. Theragra chalcogramma. Age-0 walleye pollock biomass as a function of year and zone. Horizontal lines: median; boxes: 1 interquartile range; whiskers: 95\% CI, dots: outliers abundance of isopods was significantly higher for transects with high abundances of Age-0 pollock than for transects with low abundances of pollock ( 0.06 vs. 0.01 individuals $\mathrm{m}^{-3} ; 95 \%$ Tukey's HSD CI of 0.023 to 0.068 ind. $\mathrm{m}^{-3}, \mathrm{p}<0.01$; ANOVA, pollock abundance $p<0.01$, pair $p>0.05$ ). The abundance of large copepods $(>2 \mathrm{~mm}$ ) was significantly higher for transects with high abundances of Age- 0 pollock (375 vs. 176 ind. $\mathrm{m}^{-3} ; 95 \%$ Tukey's HSD CI of 67.6 to 328.7 ind. $\mathrm{m}^{-3}, \mathrm{p}<0.05$; ANOVA, pollock abundance $\mathrm{p}<0.05$, pair $\mathrm{p}<0.05)$.

\section{Pollock vertical distribution}

In addition to the difference in overall Age-0 pollock biomass between the $2 \mathrm{yr}$, there were also significant inter-annual differences in their vertical distribution in the water column (Figs. 1 \& 2). Pollock median depth was significantly deeper in 2009 than 
in 2008 (30.0 vs. 20.0 m; ANOVA, p < 0.001; $t$-test, p < $0.001 ; 95 \%$ paired $t$-test CI of 5.15 to $17.23 \mathrm{~m}, \mathrm{p}<$ 0.001).

A MLR model showed that pollock median depth is affected by the temperature structure within the water column such that:

Pollock median depth $=$

$\beta_{0}-\beta_{1}$ (temperature at the pollock

median depth) $+\beta_{2}$ (mean temperature

above the thermocline) +

$\beta_{3}$ (thermocline depth)

where $\beta_{0}$ is the model intercept and $\beta_{1}, \beta_{2}$, and $\beta_{3}$ are the slopes. Model coefficients for the MLR model are summarized in Table 2. The additive linear model explained $62 \%$ (adj. $\mathrm{R}^{2}$ ) of the variability in the 2008 median pollock depth (MLR, p < 0.0001) and $71 \%$ (adj. $\mathrm{R}^{2}$ ) of the variability in the 2009 median pollock depth (MLR, p < 0.0001). The additive linear model explained $70 \%\left(\operatorname{adj} . \mathrm{R}^{2}\right.$ ) of the variability in the pollock median depth for both years combined, with sample year added into the model (MLR, p < 0.0001). The temperature at the pollock median depth did not vary significantly with year or zone (ANOVA, p > 0.05). The temperature at the pollock median depth was significantly higher at night than during the day (6.6 vs. $5.6^{\circ} \mathrm{C}$; Tukey's HSD $95 \%$ CI of 0.35 to $1.68^{\circ} \mathrm{C}$, $\mathrm{p}<0.01$; ANOVA $\mathrm{p}<0.01)$, indicative of diel movement of the fish rather than a direct change in the physical environment.

Age-0 pollock median depth varied with sampling zone (MS: $19.1 \mathrm{~m}$; OS: $26.7 \mathrm{~m}$; SL: $34.5 \mathrm{~m}$ ) and time of day (Day: $27.5 \mathrm{~m}$; Night: $17.0 \mathrm{~m}$ ) (ANOVA, zone: p < 0.0001, time of day: $p<0.001$; Fig. 5). Age-0 pollock median depth was significantly deeper in the Outer Shelf Zone than in the Middle Shelf Zone (Tukey's HSD $95 \%$ CI of 4.11 to 16.77 m, p < 0.001), and significantly deeper in the Slope Zone than in the Middle Shelf Zone (Tukey's HSD 95\% CI of 7.77 to 23.32 m, $\mathrm{p}<0.0001)$. There was no significant difference in pollock median depth between the Outer Shelf and Slope (Tukey's HSD, p > 0.05). Diel vertical migration of Age-0 pollock was seen in both years (combined data shown in Fig. 5); Age-0 pollock median depth was significantly deeper during the day than at night (Tukey's HSD 95\% CI of 3.18 to $15.03 \mathrm{~m}, \mathrm{p}<0.01$; ANOVA, $\mathrm{p}<0.01)$. Time of day and zone were tested as factors in the MLR model describing median pollock depth. However, despite the significant effect of time of day and zone on pollock median depth, these factors were not significant in predicting the overall depth distribution of juvenile walleye pollock in the MLR (MLR, time of day: $p>0.05$, zone: $p>0.05$ ).

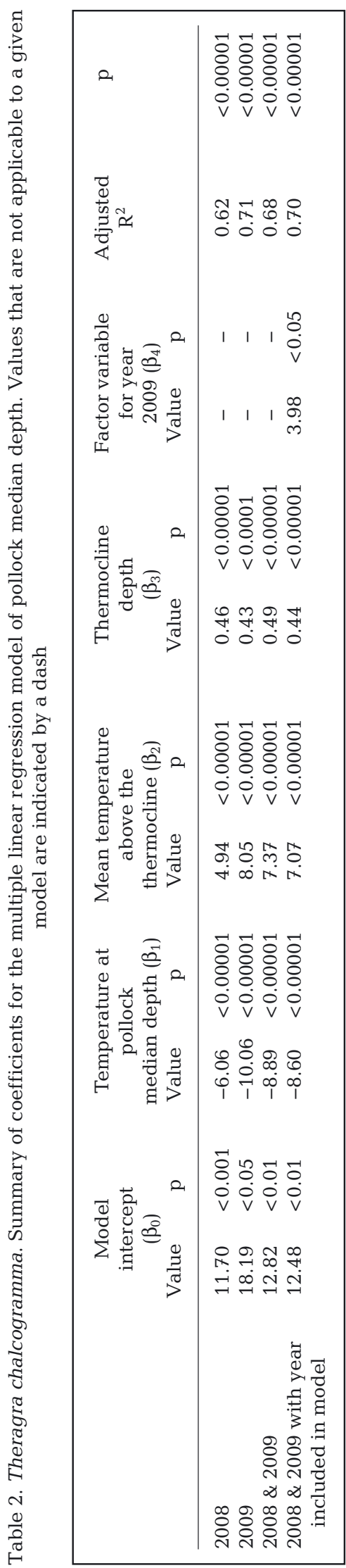




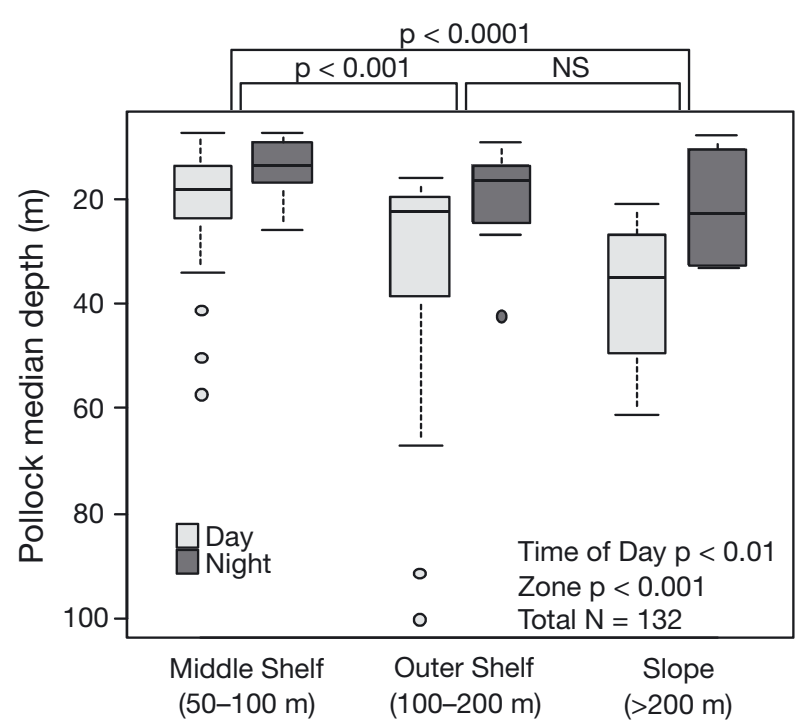

Fig. 5. Theragra chalcogramma. Age-0 walleye pollock median depth as a function of time of day and study region pooled across sampling years. Horizontal lines: median; boxes: 1 interquartile range; whiskers: $95 \% \mathrm{CI}$, dots: outliers. In each zone, day and night were significantly different $(\mathrm{p}<$ 0.01). NS: not significant
Age-0 pollock occurred over a larger average depth range (pollock maximum depth to pollock minimum depth) in 2009 than in 2008 (26.4 vs. $16.0 \mathrm{~m}$; Tukey's HSD 95\% CI of 3.77 to $15.61 \mathrm{~m}$, p < 0.01 ; ANOVA, $\mathrm{p}<0.01 ; 95 \%$ paired $t$-test CI of 4.61 to $17.21 \mathrm{~m}, \mathrm{p}<0.01)$. Age-0 pollock median depth relative to the thermocline depth also varied with year and time of day (ANOVA, year: $\mathrm{p}<0.01$; time of day: $\mathrm{p}<0.001$; Fig. 6 shows an example). After accounting for time of day, juvenile pollock median depth was above the thermocline in 2008 (mean difference: $4.0 \mathrm{~m}$ ) and below the thermocline in 2009 (mean difference: $-3.73 \mathrm{~m})$ (95\% Tukey's HSD CI of 1.88 to $13.56 \mathrm{~m}$ [2009 minus 2008], p < 0.01). After accounting for interannual differences, Age-0 pollock were found below the thermocline during the day (mean difference: $-2.68 \mathrm{~m}$ ) and above the thermocline at night (mean difference: $9.15 \mathrm{~m}$ ) (95\% Tukey's HSD CI of 5.17 to $18.5 \mathrm{~m}$ [day minus night], $\mathrm{p}<0.001$ ). There was no significant difference in thermocline depths between the 2 sample years for all transects (ANOVA, p > 0.05), but for those transects with

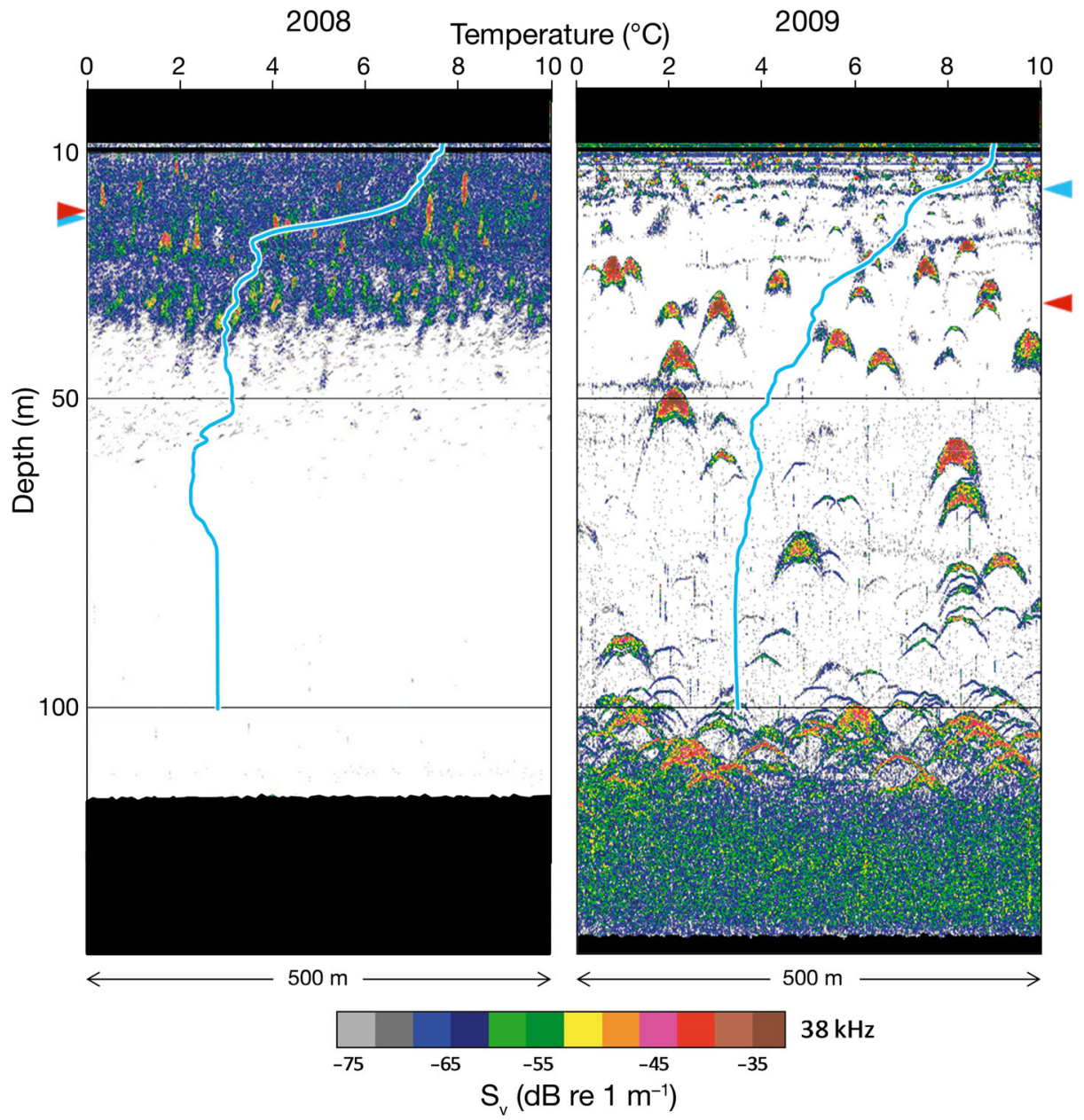

Fig. 6. Theragra chalcogramma. Two representative $38 \mathrm{kHz}$ echograms from daytime outer shelf transects with temperature profiles from the transect overlaid (blue lines). Blue triangles identify the depth of the thermocline; red triangles identify the median depth of pollock at the same location. On the left is a $500 \mathrm{~m}$ section of a transect from 2008 showing aggregations of juvenile pollock patches near the thermocline $(20.7 \mathrm{~m})$. On the right is a $500 \mathrm{~m}$ section of a transect from 2009 showing much deeper juvenile pollock patches that are below the thermocline $(16.5 \mathrm{~m})$. Median pollock depth was $20 \mathrm{~m}$ for the 2008 transect (left) and $35 \mathrm{~m}$ for the 2009 transect (right) 
acoustically identified Age-0 pollock, the thermocline was deeper in 2009 (mean: $27.7 \mathrm{~m}$ ) than in 2008 (mean: 22.8) (ANOVA, p < 0.05).

\section{Pollock patches}

The proportion of total juvenile pollock biomass that was within patches was greater in 2009 than in 2008 (63 vs $54 \%$; 95\% Tukey's HSD CI of 1 to $18 \%$, $\mathrm{p}<0.05$; ANOVA, $\mathrm{p}<0.05$ ) (Fig. 2 shows an example). The proportion of juvenile pollock biomass that was within patches did not vary by zone (ANOVA, $p>0.05)$. No significant relationship was found between the biomass within pollock patches and any of the explanatory variables used in the MLR horizontal model selection.

The biomass within pollock patches varied with zone (MS: $45.9 \mathrm{~g}$ pollock $\mathrm{m}^{-2}$; OS: $30.4 \mathrm{~g}_{\text {pollock m}}{ }^{-2}$;

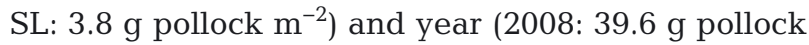
$\mathrm{m}^{-2}$; 2009: $22.7 \mathrm{~g}$ pollock $\mathrm{m}^{-2}$ ), with a significant interaction between zone and year (ANOVA, p < 0.0001). After accounting for zone effects, pollock biomass within patches was greater in 2008 than in 2009 (95\% Tukey's HSD CI of 0.04 to $0.06 \mathrm{~g}$ pollock $\mathrm{m}^{-2}, \mathrm{p}<0.0001$; ANOVA, $\mathrm{p}<0.0001$ ). After accounting for year, pollock biomass within patches was significantly greater in the Middle Shelf Zone than in the Slope Zone (95\% Tukey's HSD CI of 0.05 to $0.07 \mathrm{~g}$ pollock $\mathrm{m}^{-2}, \mathrm{p}<0.0001$ ), and significantly greater in the Outer Shelf Zone than in the Slope Zone (95\% Tukey's HSD CI of 0.04 to $0.07 \mathrm{~g}$ pollock $\mathrm{m}^{-2}, \mathrm{p}<$ 0.0001); there was no significant difference in pollock biomass within patches between the Middle Shelf and Outer Shelf (Tukey's HSD, $p>0.05$ ).

Pollock patches were significantly deeper in 2009 than in 2008 ( 29.0 vs. 21.3 m; $95 \%$ Tukey's HSD CI of 2.68 to $12.82 \mathrm{~m}, \mathrm{p}<0.01$; ANOVA, $\mathrm{p}<0.01$ ).
Mean patch depth was significantly deeper during the day than at night, after accounting for study year $(26.8$ vs. $21.4 \mathrm{~m}$ 95\% Tukey's HSD CI of 7.87 to $13.33 \mathrm{~m}, \mathrm{p}<0.01$; ANOVA, $\mathrm{p}<0.01$ ), but the mean depth of pollock patches did not vary significantly with zone (ANOVA, p > 0.05). Substituting the mean depth of pollock patches into the MLR model for the overall median depth of all pollock (Eq. 1) continued to yield a significant relationship (MLR, p < 0.0001), but explained significantly less of the variability for the pollock patches (MLR, adj. $\mathrm{R}^{2}=20 \%$ ). Additionally, thermocline depth and the mean temperature above the thermocline were no longer significant as explanatory variables (MLR, $\mathrm{p}>0.05)$.

The geometric and density characteristics of patches of pollock are summarized in Tables $3 \& 4$ for all data and excluding the patches over the middle shelf in 2008. Most of the variation in patch geometry and density were accounted for by the unique patches observed in the middle shelf in 2008 (Fig. 7). There were no effects of time of day on any of the patch characteristics examined without the 2008 middle shelf pollock patches. Simple linear regressions showed that there were no significant relationships between patch characteristics and the depth of these patches ( $p>0.05$ for all comparisons). Together, these results indicate that diel vertical migration does not change the geometric and density characteristics of patches.

The internal structure and variation within patches, measures used to characterize fish schools, are summarized in Table 5. Patches more closely approximated typical fish schools in 2009 than in 2008 for many of the measured characteristics of patch structure and variation (Table 5). Zone effects were also present for these characteristics. Patches over the slope were most consistently school-like.

Table 3. Theragra chalcogramma. Summary of ANOVAs conducted on all pollock patches and then repeated without including the patches found in 2008 over the middle shelf $\left(\mathrm{MS}_{;}<100 \mathrm{~m}\right.$ bottom depth). NS: not significant. Significance: ${ }^{*} \mathrm{p}<0.05$, ${ }^{* *} \mathrm{p}<0.01,{ }^{* * *} \mathrm{p}<0.001,{ }^{* * * *} \mathrm{p}<0.0001$

\begin{tabular}{|c|c|c|c|c|c|c|c|c|c|c|c|}
\hline \multirow[b]{3}{*}{ Patch length (m) } & & & \multicolumn{7}{|c|}{ ANOVA (all data I without 2008 MS data) } & \multirow{2}{*}{\multicolumn{2}{|c|}{ Year $\times$ Time }} \\
\hline & \multicolumn{2}{|c|}{ Year } & \multicolumn{2}{|c|}{ Zone } & \multicolumn{2}{|c|}{ Time of Day } & \multicolumn{3}{|c|}{ Year $\times$ Zone } & & \\
\hline & ** & I NS & ${ }^{* * *} \quad$ | & I NS & $* *$ & I NS & NS & । & NS & $* * * * \quad \mid$ & NS \\
\hline Patch height (m) & $* * * *$ & | ** & $* \quad 1$ & I NS & * & I NS & NS & । & NS & NS । & NS \\
\hline Patch area $\left(\mathrm{m}^{2}\right)$ & $* * * *$ & $1 \quad *$ & $* * * * \mid$ & I NS & $* * * *$ & I NS & NS & । & NS & $* * * * \quad \mid$ & NS \\
\hline Patch perimeter $(\mathrm{m})$ & *** & $\left.\right|^{* * *}$ & *** | & I NS & * & I NS & $* * *$ & I & * & ${ }^{* * *} \quad \mid$ & NS \\
\hline Numerical density (fish $\mathrm{m}^{-3}$ ) & NS & I NS & $*$ & | * & NS & I NS & NS & । & NS & NS । & NS \\
\hline Pollock spacing (body lengths) & & I NS & ** | & I NS & NS & I NS & $* *$ & । & NS & NS । & NS \\
\hline Number of pollock per patch (fish) & & I NS & ${ }^{* *} \quad \mid$ & I NS & NS & I NS & $* * *$ & । & NS & NS । & NS \\
\hline
\end{tabular}


Table 4. Theragra chalcogramma. Summary post hoc analyses for year and zone effects (OS: Outer Shelf Zone [<100 m bottom depth]; MS: Middle Shelf Zone [100 to $200 \mathrm{~m}$ bottom depth]; SL: Slope Zone [ $>200 \mathrm{~m}$ bottom depth]) on patch characteristics. Values are $95 \%$ CIs of Tukey's honestly significant difference (HSD) test. NS: not significant. Significance: ${ }^{*} \mathrm{p}<0.05,{ }^{* *} \mathrm{p}<0.01$, ${ }^{* * *} \mathrm{p}<0.001,{ }^{* * * *} \mathrm{p}<0.0001$

\begin{tabular}{|c|c|c|c|c|c|}
\hline & & & \multirow{2}{*}{$\begin{array}{r}\text { Tukey's HSD } \\
\text { MS-SL }\end{array}$} & \multirow[b]{2}{*}{ OS-SL } & \multirow[b]{2}{*}{ Night-Day } \\
\hline & 2008-2009 & MS-OS & & & \\
\hline Patch length (m) & $0.03-0.69^{* * * *}$ & $0.59-9.02^{*}$ & $0.08-10.49^{*}$ & NS & $4.54-11.66^{* * * *}$ \\
\hline Patch height (m) & $0.30-0.69^{* * * *}$ & NS & $0.06-0.76^{*}$ & NS & $-0.02-0.05^{*}$ \\
\hline Patch area $\left(\mathrm{m}^{2}\right)$ & $30.35-62.88^{* * * *}$ & $8.27-51.69^{* *}$ & NS & NS & $32.17-68.78^{* * * *}$ \\
\hline Patch perimeter $(\mathrm{m})$ & $124.79-199.48^{* * * *}$ & $38.73-138.42^{* * *}$ & $20.37-143.56^{* *}$ & NS & $80.91-165.04^{* * *}$ \\
\hline Numerical density (fish $\mathrm{m}^{-3}$ ) & NS & NS & $-0.64-6.94^{*}$ & $-0.8-6.52^{*}$ & NS \\
\hline Pollock spacing (body lengths) & $3.63-7.11^{* * * *}$ & $3.65-8.31^{* * * *}$ & $4.01-9.68^{* * * *}$ & NS & NS \\
\hline Number of pollock per patch (fish) & $2.35-6.86^{* * * *}$ & $1.09-4.54^{*}$ & NS & NS & NS \\
\hline
\end{tabular}
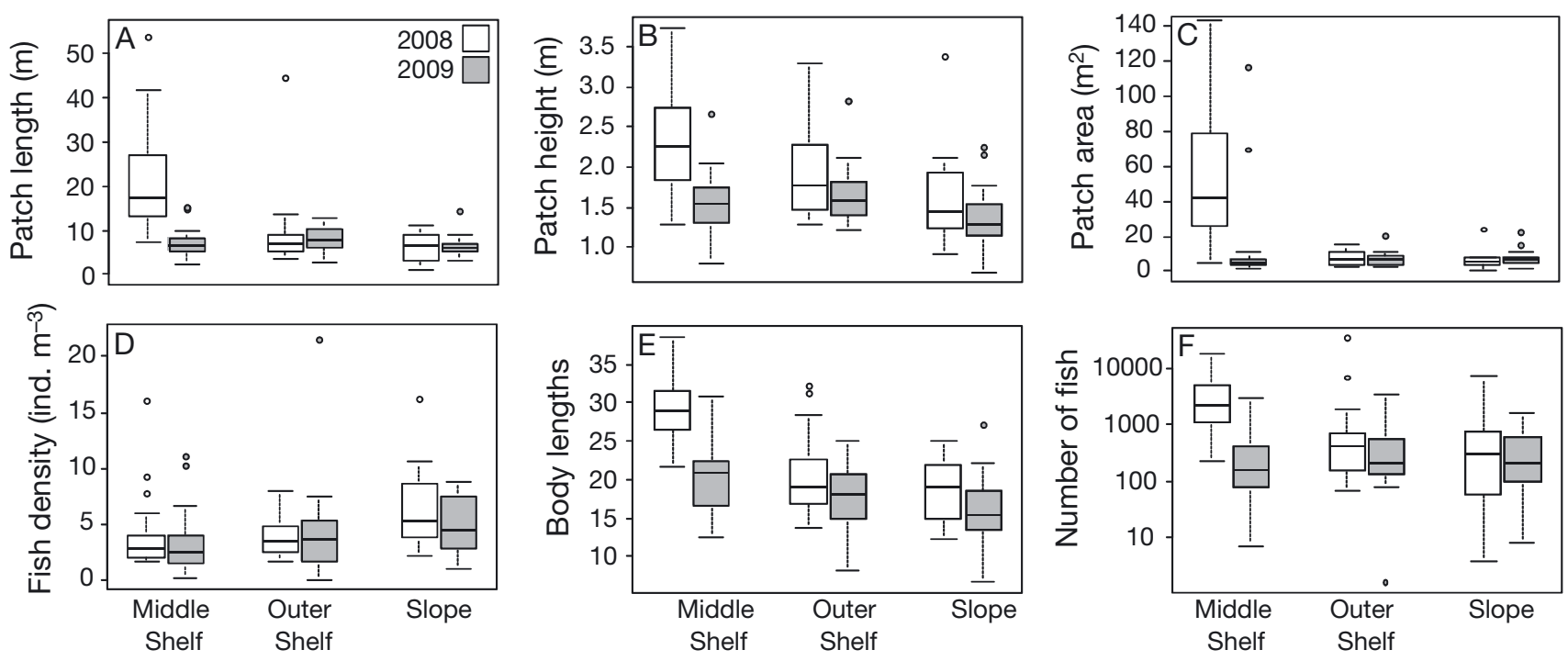

Fig. 7. Theragra chalcogramma. (A) Mean patch length, (B) mean patch height, (C) mean patch area, (D) fish numerical density, (E) nearest neighbor distance in body lengths, and (F) number of fish in each patch for aggregations of Age-0 pollock separated by year and by zone. Box plot descriptions as in Fig. 4

\section{DISCUSSION}

Juvenile walleye pollock Theragra chalcogramma in the southeastern Bering Sea were patchily distributed at the full range of spatial scales examined in this study $\left(10^{0.5}\right.$ to $\left.10^{5} \mathrm{~m}\right)$ (Fig. 8). These patches, and the gaps between them, were hierarchically nested, with small, dense patches clustered together into larger aggregations which were themselves sometimes embedded within a diffuse layer of pollock. Aggregations were also apparent at the regional scale, with clusters of transects having high pollock biomass (Fig. 1). At all levels, the spaces between pollock patches were similar to the scales of the patches themselves. As has been shown in both marine and terrestrial environments, aggregations in a system often exist across a range of scales in a hierar- chical mosaic (Wu \& Loucks 1995), with small, highdensity patches nested inside of larger, lower density aggregations (Kotliar \& Wiens 1990). The structure of patch hierarchies affects foraging behavior, habitat selection, and population dynamics (Kotliar \& Wiens 1990) and has become a central theme in the field of landscape ecology (Wiens 1989, Zhang \& Sanderson 1993, Girvetz \& Greco 2007).

While studies of hierarchically structured patchiness in marine systems remain limited in number (Girvetz \& Greco 2007), it is clear that one must consider more than a single scale of patchiness to understand the consequences of heterogeneous distributions (Wiens 1985). Field studies of pollock in the Bering Sea designed for stock assessment have focused on the regional scale (Ciannelli et al. 2002, Ressler et al. 2012), while laboratory efforts (Ryer \& 


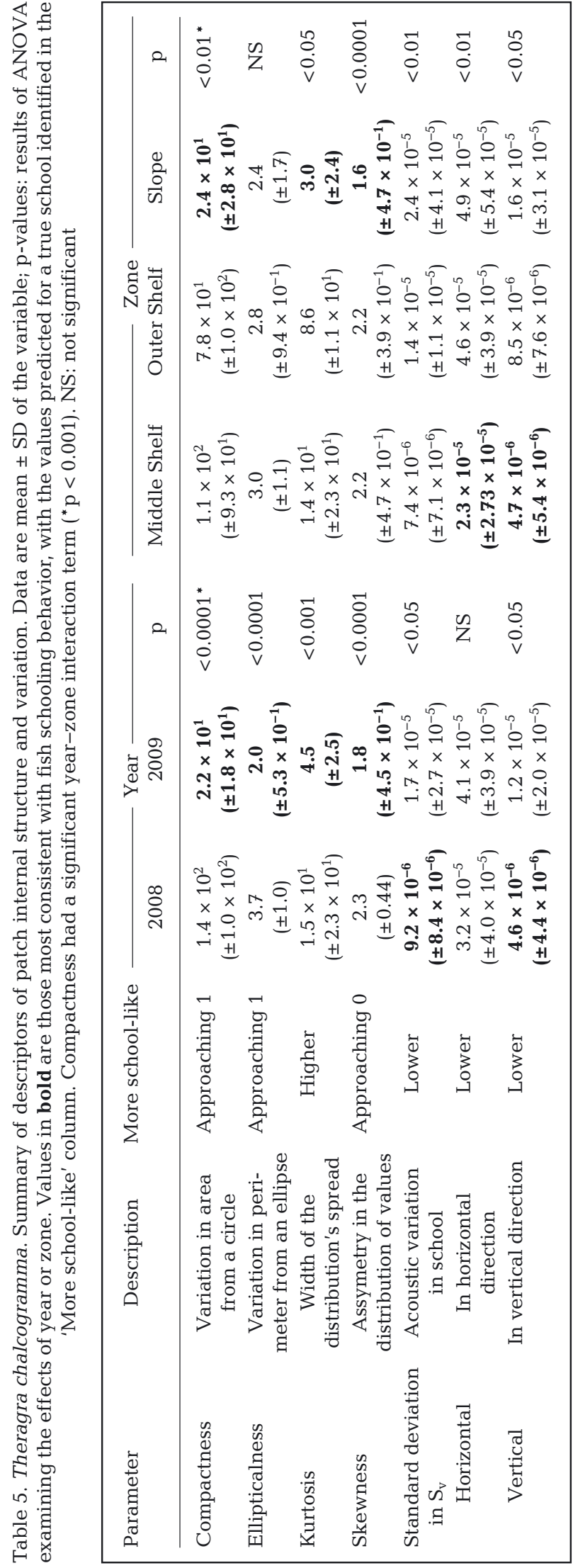

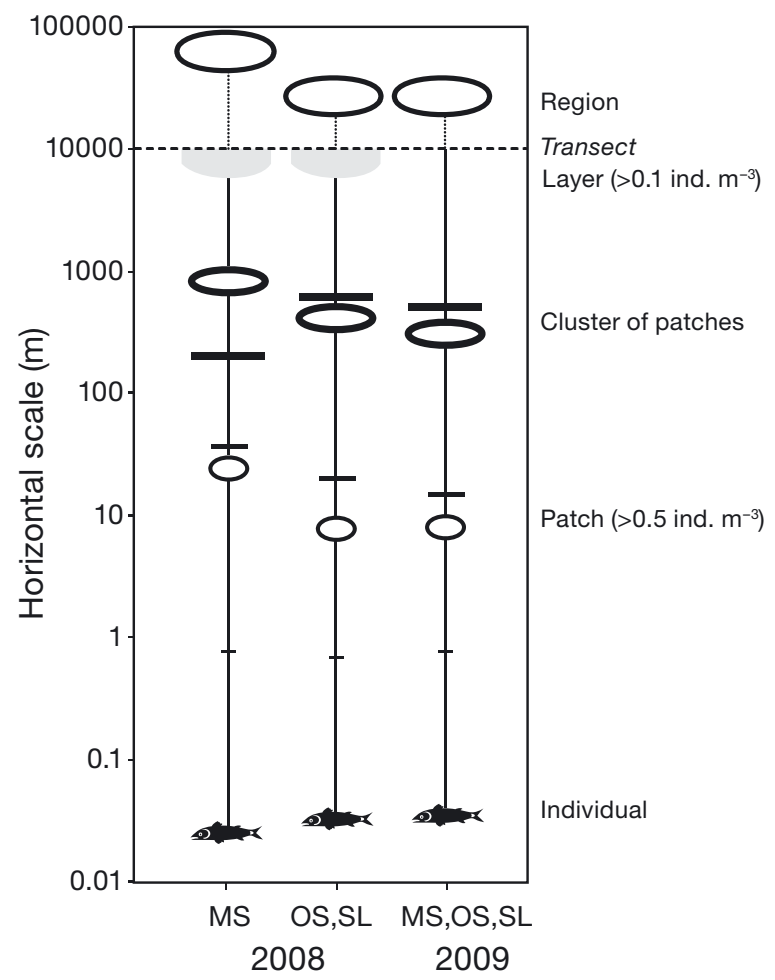

Fig. 8. Theragra chalcogramma. Graphical representation of the nested hierarchical nature of juvenile walleye pollock and the mean horizontal scale at which each level in the hierarchy occurred in each year, with the 2008 middle shelf samples shown separately. Fish icons are located along the $y$-axis in relation to measured individual lengths for each year. The scale of aggregations is denoted by the location of ovals, while correspondingly sized and weighted horizontal lines denote the scales of the spaces between units at that level in the hierarchy. Loosely aggregated layers of pollock are indicated in gray - the full range of scales of layers could not be determined because they ranged from approximately $1 \mathrm{~km}$ to greater than the full length of a transect $(10 \mathrm{~km})$. MS: Middle Shelf Zone; OS: Outer Shelf Zone; SL: Slope Zone

Olla 1992, 1995, 1998) and some field programs (Swartzman et al. 1994, 2002) have examined individual pollock schools. To scale up from studies of individuals and schools to data measured in largescale surveys, it is critical to identify the intervening scales (Wiens 1985). Examining the scale-dependent aggregation of pollock and the linkages between these features will likely provide information critical to understanding the mechanisms that drive the distribution of juvenile pollock.

Both years of our study were cold years in the Bering Sea (Hunt et al. 2011). Despite largely similar physical characteristics (e.g. $<1^{\circ} \mathrm{C}$ difference in seasurface temperature, mean temperature below the thermocline, and depth-averaged temperature be- 
tween the 2 years), there were significant differences in the distribution, patch structure, and abundance of juvenile pollock between the 2 years. First, Age-0 pollock were more abundant in 2008 than in 2009, and were more patchily distributed at the regional scale, with a smaller proportion of transects surveyed containing patches. In addition, in 2008, across the entire study area, pollock patches were nested within low-density layers of pollock which were rarely observed in 2009 (Fig. 6). This was quantified as the proportion of the pollock biomass contained in small, dense patches, which was significantly higher in 2009 than in 2008. The diffuse layers observed in 2008 added an additional level of spatial structure to the overall distribution observed in juvenile pollock.

The most striking differences observed between years are accounted for by pollock in 2008 on the middle shelf (shallower than $100 \mathrm{~m}$ ). Pollock found over the middle shelf in 2008 were quite different than those found in deeper waters and ones found in 2009. The 2008 middle shelf pollock were about $13 \mathrm{~mm}$ smaller than those found in 2009, while those pollock found in deeper waters in 2008 were only $3 \mathrm{~mm}$ smaller than the 2009 mean of $37 \mathrm{~mm}$ (Fig. 3). Pollock over the middle shelf in 2008 were also very differently distributed than all other observations, with larger individual pollock patches comprised of more individuals that were less densely packed (Fig. 8). These patches were clustered in larger aggregations than other pollock patches and were separated from other clusters by shorter distances than those found in deeper waters or in 2009 (Fig. 7).

Removing the 2008 middle shelf pollock from analyses reduced much of the variability in pollock patch characteristics between years (Table 3). However, despite similarities in the geometry and density of patches between years, some distinct differences were observed in the characteristics of patches that can be used to assess how consistent aggregations are with schools, or discretely bounded aggregations made up of polarized individuals (Pitcher \& Parrish 1993) (Table 5). Patches of juvenile pollock were more 'school-like' in 2009 than in 2008, with compact, elliptical shapes with relatively even internal structure. Interestingly, in both years, the most 'school-like' aggregations were found over slope waters, with the aggregations over the middle shelf the least consistent with true schooling in both years. These results suggest differences in the intensity of predation pressure between years and zones, as experimental work has shown that juvenile pollock swim in loose groups when no predators are present, but form cohesive schools in the presence of pre- dators (Ryer \& Olla 1998). However, a priori, we expected predation pressure to be highest over the shelf and weakest over the slope, resulting in more aggregation over the shelf, the opposite of the observed pattern. Distance from the colony, unlike bathymetric zone, did not show a significant relationship with juvenile pollock aggregation.

The counterintuitive patterns in pollock aggregation may have to do with variation in pollock prey distributions. In laboratory experiments, pollock did not form groups under any conditions when food was dispersed (Ryer \& Olla 1998). While we can infer that the prey of juvenile pollock were likely patchy at scales the pollock could perceive and respond to during our study, future efforts must describe the spatial scales in the distribution of pollock prey to understand pollock distributions. Interestingly, in all of our observations, patches of pollock (except in 2008 over the middle shelf) contained approximately the same number of individuals, roughly a few hundred, suggesting that the mechanisms for the formation of the groups themselves were consistent across conditions, even while the conditions leading to group cohesion (e.g. schooling) vary.

Despite differences in the abundance and distributional characteristics of juvenile pollock observed between study years, in both years, the environmental variables we evaluated were not able to explain variations in the horizontal distribution of Age-0 pollock either in patches or within layers. The best linear models had many factors $(>5)$ and explained little $(<40 \%)$ of the Age-0 pollock horizontal distribution variability. This agrees with previous studies that found that Age-0 pollock did not seem to aggregate in any particular habitat (Brodeur et al. 2002), and that Age- 0 pollock distributions may be affected by different factors in different geographical areas (i.e. frontal region, shelf) and that these factors might vary in importance in different years (Ciannelli et al. 2002). All of our parameters, except distance from the nearest colony, measured potentially bottom-up controls, so it is possible that top-down controls like predation by fish may be more important in determining the horizontal distribution of juvenile walleye pollock.

Another explanation for the limited correlation between our habitat descriptors and juvenile pollock distributions is that the descriptors were too coarsely resolved. We were unable to measure habitat at the scale of the individual pollock or for each pollock patch, the scale at which these factors likely impact pollock behavior. Our choices of metrics were similarly coarse. For example, we examined the effects of 
zooplankton only in terms of integrated biomass. It is perhaps not surprising that we found no relationship between pollock distribution and mesozooplankton. In fact, we found opposing trends in mesozoplankton biomass and Age-0 pollock biomass between years. We know that not all zooplankton are equally likely to be preyed upon by pollock, which likely contributed to this apparent mismatch. Coyle et al. (2008) found that while copepods were always an important prey item for Age-0 pollock, large copepods were more abundant and were consumed in the cold year they sampled, but smaller copepods were more abundant and were consumed during a warm year. Similar to other studies in this area (Brodeur et al. 2002, Ciannelli et al. 2002, Swartzman et al. 2002, Winter et al. 2005), we found that Age-0 pollock distributions were most variable in the Outer Shelf Zone, so we chose this zone for further analysis of the 2009 zooplankton samples. At the transect scale, pollock abundance was correlated with the abundance of large calanoid copepods, similar to the results of Coyle et al. (2008), indicating that this system may be controlled from the bottom up. It is likely that the species and size of zooplankton potential prey are important predictors of where Age-0 pollock are found. However, examining this parameter at the spatial scales important to juvenile pollock presents a formidable challenge.

Unlike the horizontal distribution of Age-0 pollock, we found significant relationships between environmental parameters and the vertical distribution of Age-0 pollock. We found that the median depth of Age-0 pollock depended on the vertical temperature structure (thermocline depth, mean temperature above the thermocline, and temperature at the median pollock depth) but was not related to typical temperature metrics such as sea-surface temperature or depth-averaged temperature as might have been expected from the oscillating control hypothesis (Hunt et al. 2002, 2011). This finding is consistent with laboratory studies showing the vertical distribution of Age- 0 pollock is most impacted by thermal stratification (Sogard \& Olla 1993). Previous field studies have shown that juvenile pollock were typically near and often above the thermocline (Swartzman et al. 1999b). We found that Age-0 pollock were near the thermocline in both years, but in 2008 most of the Age- 0 pollock were 5 to $10 \mathrm{~m}$ above and in 2009 they were a similar distance below the thermocline despite both thermocline depth and temperature gradient across the thermocline not varying significantly between years. The offset between fish and the thermocline was not related to the size of individ- uals, as has been observed in previous field surveys (Bailey 1989). Our results indicate that the vertical distribution of juvenile pollock is driven by more than a simple association with the thermocline, a conclusion also drawn from previous laboratory studies (e.g. Olla et al. 1995).

Age-0 pollock were located much deeper in the water column, and had a larger vertical range in 2009 than in 2008. During both years we observed that Age-0 pollock were found deeper during the day and shallower at night, consistent with diel vertical migration behavior. Interestingly, the spatial patterns we observed in juvenile pollock did not change with vertical migration, unlike laboratory observations (Sogard \& Olla 1997). Both schooling and diel migration are thought to be involved in enhancing feeding and avoiding predation. Our observations suggest that the optimal geometry for individuals in schools remains unchanged over the day-night cycle despite likely diel changes in the tradeoffs of these behaviors. This may reflect high predation risk over the entire day-night cycle: during daylight from predators like arrowtooth flounder (Lang et al. 2000) and during darkness from animals like fur seals that, during this study, foraged most heavily at night (BenoitBird et al. 2013).

Diel vertical migration has been previously reported for Age-0 pollock in the Bering Sea in late summer (Schabetsberger et al. 2000) and autumn (Bailey 1989), but not for Age-0 pollock as small as those observed here (average length $<40 \mathrm{~mm}$ ). However, diel vertical excursions of similar extents have been observed in larval pollock ( 10 mm long) (Kendall et al. 1994, Smart et al. 2013). While diel vertical migrations of 5 to $20 \mathrm{~m}$ were observed in both years, in all zones, the observed migration of juvenile pollock in 2009 was approximately double that observed in 2008. This may be due in part to the difference in fish size between the 2 years, as it is known that larger juvenile pollock exhibit larger vertical migrations (Bailey 1989). Laboratory studies have shown ontogenetic shifts in vertical migration behavior with smaller Age-0 pollock avoiding cold water and spending less time below the thermocline than larger fish, likely due to an increased tolerance to cold water, the benefits of migrating below the thermocline being outweighed by the risks, and the potential for small fish to increase their growth rates in warmer waters (Sogard \& Olla 1993). However, the relationship between depth and body length is complicated, evidenced by the lack of relationship between these 2 variables in our model selection. 
Slow-swimming animals such as Age-0 pollock may experience more environmental variation by moving vertically in the water column than horizontally, so while they may have little control over their horizontal location they are likely able to find better conditions by changing their vertical position. This may be why we were better able to explain vertical distribution patterns than horizontal distribution patterns of pollock layers and patches. Interestingly, the patterns we found in the vertical distribution were consistent between our study years and across bathymetric zones, despite inherent oceanographic differences among zones. However, the factors we identified as influencing the vertical distribution of Age-0 pollock require in situ sampling; sea-surface temperature and other potentially remotely sensed variables did not accurately predict the vertical distribution of juvenile pollock during our sampling period.

Our findings have implications for how juvenile pollock in the southeastern Bering Sea are best sampled, and how the observed distributional patterns are interpreted. Very few data are available on the distribution of juvenile pollock over shelf and slope waters (Honkalehto \& Center 2002). Ongoing, standardized surveys of pollock distribution in the Bering Sea, such as those conducted by the NOAA Fisheries Alaska Fisheries Science Center in support of pollock stock assessment, do not consistently sample these areas since it is thought that juvenile pollock avoid deep water. However, we found that the biomass density of juvenile pollock in the slope waters we sampled was not significantly different from that of the outer shelf. At least during the cold years we sampled, ignoring these regions, which make up a substantial area of the Bering Sea, could lead to a significant underestimation of potential year class strength. Furthermore, we found that most of the juvenile pollock biomass was at depths $>20 \mathrm{~m}$, with more than half of the biomass in 2009 deeper than $50 \mathrm{~m}$, although the pollock patches never approached the seafloor. This midwater distribution (Fig. 1), which is not sampled by the currently used surface and benthic trawls in surveys of pollock, could also lead to significantly bias biomass estimates, as well as other data derived from samples such as energy density.

This study was conducted as an element of a larger, interdisciplinary program aimed at understanding the population dynamics and behavior of marine birds and fur seals breeding on the Pribilof Islands. The distribution and thus accessibility of juvenile pollock has strong impacts on the reproductive success of these predators (Zeppelin \& Ream 2006, Ren- ner et al. 2012). Many of the factors that varied in juvenile pollock likely affect foraging by these predators. These effects, however, are clearly complicated, as the distribution of pollock likely had different impacts at the different scales observed. For example, between years, the depth of pollock was quite different, resulting in different costs for airbreathing predators foraging on pollock (Croll et al. 1992). In 2008, even though pollock were found higher in the water column and (over the shelf) were abundant and in large, closely spaced patches that were relatively close to predator breeding colonies, individual pollock were also very small. These small pollock had lower energy per unit weight than larger pollock (3.1 and $3.5 \mathrm{~kJ} \mathrm{~g}^{-1}$, in 2008 and 2009, respectively), which, coupled with their overall small size, made them a low-value prey $\left(1.4 \mathrm{~kJ} \mathrm{ind}^{-1}\right.$ in 2008 versus $1.9 \mathrm{~kJ}$ ind. ${ }^{-1}$ in 2009) (Whitman 2010). Low costs to prey acquisition in 2008 may have been tempered by only small energy gains for predators that consume prey one at a time (e.g. fur seals and marine birds rather than large whales).

At even smaller spatial and likely temporal scales, variation in the coherence or the degree of schooling of fish within patches can affect the ability of predators to capture these individuals while simultaneously changing the conspicuousness of prey (Brock \& Riffenburgh 1959, Magurran 1990). Perhaps more important for predators than the variability in pollock spatial dynamics at a specific scale, our analysis identified the hierarchically nested nature of juvenile pollock distribution. Predator search efficiencies are predicted to be greater in hierarchically nested prey systems such as we have seen for pollock as opposed to the largely unstructured spatial dynamics for other potential prey, for example mesopelagic prey like myctophids and squid, in this system (Fauchald 2009). The tendency for juvenile pollock to school and for those schools to further cluster into larger patches leads to spatial predictability for predators. Put another way, once one patch is found, finding a second patch is much more likely. In addition, the radius to the next patch is relatively narrowly constrained, allowing efficient searching. This has resulted in some predators like northern fur seals showing a tight coupling in their search strategies with the distribution of juvenile pollock even when other prey make up a substantial part of their diet (Benoit-Bird et al. 2013). However, small changes in scale also change the variance structure of the system, resulting in large effects on prey encounter rates and the ideal time for a predator to forage within a patch (Charnov 1976, Krebs 1978, Kotliar \& Wiens 
1990). The spatial distribution of Age-0 pollock in the southeastern Bering Sea presents an opportunity to understand which of these pollock features impact the distributions of predators. The data presented here are being used in partnered studies to understand the dynamics of several predators in the Bering Sea: thick-billed murres Uria lomvia, black-legged kittiwakes Rissa tridactyla, and northern fur seals Callorhinus ursinus.

In the summers of 2 cold years, Age- 0 pollock were patchily distributed at scales ranging from a few meters to a few tens of kilometers. These aggregations were hierarchically nested, with high-density aggregations nested in lower density features at increasingly larger spatial scales. This has important implications for the analysis of these data as non-stationarity is a key property of hierarchical patch systems (e.g. the probability of a spatial process is unequal throughout space). Thus, the results from global analyses of spatial structure (variograms, correlograms, spectral analyses, wavelets, and fractals) are highly confounded, such that large-scale patterns mask nested small-scale patterns (Fauchald et al. 2000).

Careful attention must be paid to the design of surveys of pollock, and how spatial distribution data are analyzed in the context of broad-scale ecosystem studies. More importantly, the understanding that pollock are distributed in nested aggregations provides a framework for linking pattern, process, and scale in this ecosystem (Wu \& Loucks 1995). Within hierarchically structured systems, larger scale processes impose constraints on lower levels, while lower level processes provide the mechanism through which higher levels of organization emerge (Kotliar \& Wiens 1990). If we are to understand the processes driving the distribution of juvenile pollock, we must include multiple scales of heterogeneity in our sampling design of both the pollock and their habitat and couple this with mechanistic models of the factors driving the behavior of individual fish (sensu Bailey 1989). Only then will we begin to understand the ecological role of pollock in the ecosystem and be able to predict the consequences of large sources of variability such as climate changea critical question in the rapidly changing physical and biological habitat of the Bering Sea (Overland \& Stabeno 2004, Stabeno et al. 2007, Hunt et al. 2011).

Acknowledgements. S. Archer, A. Dauble, G. Kowalke, C. Waluk, and L. Whitman provided assistance in the field. L. Jasiuk assisted in the laboratory processing of data. J. Condiotty of Simrad, C. Wingard, T. Cowles, R. Emmett,
M. Torres, C. Miller, M. J. Zirbel, R. Letelier, and M. McManus lent equipment used in the study. A. Trites facilitated collaboration among research teams in the larger program. The captains and crews of the FV 'Frosti' \& FV 'Gold Rush' provided exceptional field support. Funding was provided by the North Pacific Research Board as part of the Bering Sea Project; this is NPRB Publication Number 417 and BEST-BSIERP Bering Sea Project Publication Number 95.

\section{LITERATURE CITED}

Angliss RP, Lodge KL (2004) Alaska marine mammal stock assessments, 2003. Report No. NMFS-AFSC-144, US Department of Commerce, Washington, DC

Bacheler NM, Ciannelli L, Bailey KM, Bartolino V (2012) Do walleye pollock exhibit flexibility in where or when they spawn based on variability in water temperature? DeepSea Res II 65-70:208-216

$>$ Bailey KM (1989) Interaction between the vertical distribution of juvenile walleye pollock Theragra chalcogramma in the eastern Bering Sea, and cannibalism. Mar Ecol Prog Ser 53:205-213

Bailey KM, Ciannelli L, Bond NA, Belgrano A, Stenseth NC (2005) Recruitment of walleye pollock in a physically and biologically complex ecosystem: a new perspective. Prog Oceanogr 67:24-42

$>$ Barange M (1994) Acoustic identification, classification and structure of biological patchiness on the edge of the Agulhas Bank and its relation to frontal features. S Afr J Mar Sci 14:333-347

Benoit-Bird KJ, Kuletz K, Heppell S, Jones N, Hoover B (2011) Active acoustic examination of the diving behavior of murres foraging on patchy prey. Mar Ecol Prog Ser 443:217-235

Benoit-Bird KJ, Battaile BC, Nordstrom CA, Trites AW (2013) Foraging behavior of northern fur seals closely matches the hierarchical patch scales of prey. Mar Ecol Prog Ser 479:283-302

Brock VE, Riffenburgh RH (1959) Fish schooling: a possible factor in reducing predation. J Cons Cons Int Explor Mer 25:301-317

> Brodeur RD (1998) Prey selection by age-0 walleye pollock, Theragra chalcogramma, in nearshore waters of the Gulf of Alaska. Environ Biol Fishes 51:175-186

Brodeur RD, Wilson MT (1996) A review of the distribution, ecology and population dynamics of age-0 walleye pollock in the Gulf of Alaska. Fish Oceanogr 5:148-166

Brodeur RD, Wilson MT, Ciannelli L, Doyle M, Napp J (2002) Interannual and regional variability in distribution and ecology of juvenile pollock and their prey in frontal structures of the Bering Sea. Deep-Sea Res II 49:6051-6067

$>$ Brown AL, Bailey KM (1992) Otolith analysis of juvenile walleye pollock Theragra chalcogramma from the western Gulf of Alaska. Mar Biol 112:23-30

Burgos JM, Horne JK (2007) Sensitivity analysis and parameter selection for detecting aggregations in acoustic data. ICES J Mar Sci 64:160-168

Charnov EL (1976) Optimal foraging, the marginal value theorem. Theor Popul Biol 9:129-136

> Ciannelli L (2002) Effects of spatial variability, associated with a frontal structure, on predictions of age- 0 walleye pollock (Theragra chalcogramma) growth around the Pribilof Islands, Bering Sea. Estuar Coast Shelf Sci 55: 151-165 
Ciannelli L, Brodeur RD, Swartzman GL, Salo S (2002) Physical and biological factors influencing the spatial distribution of age-0 walleye pollock (Theragra chalcogramma) around the Pribilof Islands, Bering Sea. Deep-Sea Res II 49:6109-6126

Coachman L (1986) Circulation, water masses, and fluxes on the southeastern Bering Sea shelf. Cont Shelf Res 5: 23-108

Coyle KO, Pinchuk AI, Eisner LB, Napp JM (2008) Zooplankton species composition, abundance and biomass on the eastern Bering Sea shelf during summer: the potential role of water-column stability and nutrients in structuring the zooplankton community. Deep-Sea Res II 55:1775-1791

> Croll D, Gaston A, Burger A, Konnoff D (1992) Foraging behavior and physiological adaptation for diving in thick-billed murres. Ecology 73:344-356

$>$ De Robertis A (2010) Development and application of an empirical multifrequency method for backscatter classification. Can J Fish Aquat Sci 67:1459-1474

> Dekshenieks MM, Donaghay PL, Sullivan JM, Rines JEB, Osborn TR, Twardowski MS (2001) Temporal and spatial occurrence of thin phytoplankton layers in relation to physical processes. Mar Ecol Prog Ser 223:61-71

> Diner N (2001) Correction on school geometry and density: approach based on acoustic image simulation. Aquat Living Resour 14:211-222

> Fauchald P (2009) Spatial interaction between seabirds and prey: review and synthesis. Mar Ecol Prog Ser 391: 139-151

Fauchald P, Erikstad KE, Skarsfjord H (2000) Scale dependent predator-prey interactions: the hierarchical spatial distribution of seabirds and prey. Ecology 81:773-783

Foote KG, Knudsen HP, Vestnes G, Maclennan DN, Simmonds EJ (1987) Calibration of acoustic instruments for fish density estimation: a practical guide. ICES Coop Res Rep 144:1-69

Girvetz EH, Greco SE (2007) How to define a patch: a spatial model for hierarchically delineating organism-specific habitat patches. Landscape Ecol 22:1131-1142

Hickey JJ, Craighead FL (1977) A census of seabirds on the Pribilof Islands. In: Final report, Vol 2. US Department of Commerce, NOAA, OCSEAP, Washington, DC, p 96-195

Honkalehto T, Center AFS (2002) Echo integration-trawl survey results for walleye pollock (Theragra chalcogramma) on the Bering Sea shelf and slope during summer 1999 and 2000. US Department of Commerce, NOAA, NMFS, Alaska Fisheries Science Center, Seattle, WA

Hunt GL Jr, Stabeno P, Walters G, Sinclair E, Brodeur RD, Napp JM, Bond NA (2002) Climate change and control of the southeastern Bering Sea pelagic ecosystem. DeepSea Res II 49:5821-5853

Hunt GL Jr, Coyle KO, Eisner LB, Farley EV and others (2011) Climate impacts on eastern Bering Sea foodwebs: a synthesis of new data and an assessment of the Oscillating Control Hypothesis. ICES J Mar Sci 68:1230-1243

Hunter MD, Price PW (1992) Playing chutes and ladders: heterogeneity and the relative roles of bottom-up and top-down forces in natural communities. Ecology 73: 724-732

Kang M, Furusawa M, Miyashita K (2002) Effective and accurate use of difference in mean volume backscattering strength to identify fish and plankton. ICES J Mar Sci 59:794-804
Kendall A, Incze L, Ortner P, Cummings S, Brown P (1994) The vertical distribution of eggs and larvae of walleye pollock, Theragra chalcogramma, in Shelikof Strait, Gulf of Alaska. Fish Bull 92:540-554

> Kinder TH, Hunt GL, Schneider D, Schumacher JD (1983) Correlations between seabirds and oceanic fronts around the Pribilof Islands, Alaska. Estuar Coast Shelf Sci 16:309-319

Korneliussen RJ, Ona E (2002) An operational system for processing and visualizing multi-frequency acoustic data. ICES J Mar Sci 59:293-313

- Kotliar NB, Wiens JA (1990) Multiple scales of patchiness and patch structure: a hierarchical framework for the study of heterogeneity. Oikos 59:253-260

Krebs JR (1978) Optimal foraging: decision rules for predators. In: Krebs JR, Davies NB (eds) Behavioural ecology, an evolutionary approach. Sinauer, Sunderland, MA, p 23-63

Lang GM, Brodeur RD, Napp JM, Schabetsberger R (2000) Variation in groundfish predation on juvenile walleye pollock relative to hydrographic structure near the Pribilof Islands, Alaska. ICES J Mar Sci 57:265-271

- Levin SA (1992) The problem of pattern and scale in ecology. Ecology 73:1943-1967

> Livingston PA (1993) Importance of predation by groundfish, marine mammals and birds on walleye pollock Theragra chalcogramma and Pacific herring Clupea pallasi in the eastern Bering Sea. Mar Ecol Prog Ser 102: 205-215

Mackas DL, Denman KL, Abbott MR (1985) Plankton patchiness: biology in the physical vernacular. Bull Mar Sci 37: 652-674

Magurran AE (1990) The adaptive significance of schooling as an anti-predator defence in fish. Ann Zool Fenn 27: $51-66$

Napp J, Kendall A, Schumacher J (2000) A synthesis of biological and physical processes affecting the feeding environment of larval walleye pollock (Theragra chalcogramma) in the eastern Bering Sea. Fish Oceanogr 9: $147-162$

Nishimura A, Yamada J (1988) Geographical differences in early growth of walleye pollock Theragra chalcogramma, estimated by back-calculation of otolith daily growth increments. Mar Biol 97:459-465

Olla BL, Davis MW, Ryer CH, Sogard SM (1995) Behavioural responses of larval and juvenile walleye pollock (Theragra chalcogramma): possible mechanisms controlling distribution and recruitment. International Council for the Exploration of the Sea, Copenhagen, p 3-15

Olla BL, Davis MW, Ryer CH, Sogard SM (1996) Behavioural determinants of distribution and survival in early stages of walleye pollock, Theragra chalcogramma a synthesis of experimental studies. Fish Oceanogr 5:167-178

Overland JE, Stabeno PJ (2004) Is the climate of the Bering Sea warming and affecting the ecosystem? Eos 85: 309-316

Pitcher TJ, Parrish JK (1993) Function of shoaling behavior in teleosts. In: Pitcher TJ (ed) Behavior of teleost fishes. Chapman \& Hall, New York, NY, p 363-439

> Renner HM, Mueter F, Drummond BA, Warzybok JA, Sinclair EH (2012) Patterns of change in diets of two piscivorous seabird species during 35 years in the Pribilof Islands. Deep-Sea Res II 65-70:273-291

Ressler PH, De Robertis A, Warren JD, Smith JN, Kotwicki S (2012) Developing an acoustic survey of euphausiids to 
understand trophic interactions in the Bering Sea ecosystem. Deep-Sea Res II 65-70:184-195

Ryer CH, Olla BL (1992) Social mechanisms facilitating exploitation of spatially variable ephemeral food patches in a pelagic marine fish. Anim Behav 44:69-74

Ryer CH, Olla BL (1995) Influences of food distribution on fish foraging behaviour. Anim Behav 49:411-418

Ryer CH, Olla BL (1997) Altered search speed and growth: social versus independent foraging in two pelagic juvenile fishes. Mar Ecol Prog Ser 153:273-281

Ryer CH, Olla BL (1998) Shifting the balance between foraging and predator avoidance: the importance of food distribution for a schooling pelagic forager. Environ Biol Fishes 52:467-475

Schabetsberger R, Brodeur RD, Ciannelli L, Napp JM, Swartzman GL (2000) Diel vertical migration and interaction of zooplankton and juvenile walleye pollock (Theragra chalcogramma) at a frontal region near the Pribilof Islands, Bering Sea. ICES J Mar Sci 57:1283-1295

Schabetsberger R, Sztatecsny M, Drozdowski G, Brodeur RD and others (2003) Size-dependent, spatial, and temporal variability of juvenile walleye pollock (Theragra chalcogramma) feeding at a structural front in the Southeast Bering Sea. PSZNI: Mar Ecol 24:141-164

Smart TI, Duffy-Anderson JT, Horne JK, Farley EV, Wilson CD, Napp JM (2012) Influence of environment on walleye pollock eggs, larvae, and juveniles in the southeastern Bering Sea. Deep-Sea Res II 65-70:196-207

Smart TI, Siddon EC, Duffy-Anderson JT (2013) Vertical distributions of the early life stages of walleye pollock (Theragra chalcogramma) in the southeastern Bering Sea. Deep-Sea Res II, doi:10.1016/j.dsr2.2013.03.030

> Sogard SM, Olla BL (1993) Effects of light, thermoclines and predator presence on vertical distribution and behavioral interactions of juvenile walleye pollock, Theragra chalcogramma Pallas. J Exp Mar Biol Ecol 167:179-195

Sogard SM, Olla BL (1997) The influence of hunger and predation risk on group cohesion in a pelagic fish, walleye pollock Theragra chalcogramma. Environ Biol Fishes 50: 405-413

Stabeno PJ, Schumacher JD, Salo SA, Hunt GL, Flint M (1999) The physical environment around the Pribilof Islands. In: Dynamics of the Bering Sea. Alaska Sea Grant, Fairbanks, AK, p 193-215

Stabeno P, Bond N, Salo S (2007) On the recent warming of the southeastern Bering Sea shelf. Deep-Sea Res II 54: 2599-2618

Steele JH (1978) Spatial pattern in plankton communities. NATO Conference Series, Marine Sciences IV, Vol 3. Plenum Press, New York, NY, p 470

Editorial responsibility: Kenneth Sherman, Narragansett, Rhode Island, USA
Swartzman G, Hunt G (2000) Spatial association between murres (Uria spp.), puffins (Fratercula spp.) and fish shoals near Pribilof Islands, Alaska. Mar Ecol Prog Ser 206:297-309

> Swartzman G, Stuetzle W, Kulman K, Powojowski M (1994) Relating the distribution of pollock schools in the Bering Sea to environmental factors. ICES J Mar Sci 51: 481-492

> Swartzman G, Brodeur R, Napp J, Walsh D and others (1999a) Relating spatial distributions of acoustically determined patches of fish and plankton: data viewing, image analysis, and spatial proximity. Can J Fish Aquat Sci 56:188-198

> Swartzman G, Brodeur RD, Napp JM, Hunt GL, Demer D, Hewitt R (1999b) Spatial proximity of age-0 walleye pollock (Theragra chalcogramma) to zooplankton near the Pribilof Islands, Bering Sea, Alaska. ICES J Mar Sci 56: 545-560

> Swartzman G, Napp J, Brodeur R, Winter A, Ciannelli L (2002) Spatial patterns of pollock and zooplankton distribution in the Pribilof Islands, Alaska nursery area and their relationship to pollock recruitment. ICES J Mar Sci 59:1167-1186

Whitman LD (2010) Variation in the energy density of forage fishes and invertebrates from the southeastern Bering Sea. MS thesis, Oregon State University, Corvallis, OR

Wiens JA (1985) Habitat selection in variable environments: shrub-steppe birds. In: Cody ML (ed) Habitat selection in birds. Academic Press, New York, NY, p 227-251

> Wiens JA (1989) Spatial scaling in ecology. Funct Ecol 3: 385-397

> Wiese FK, Wiseman WJ, Van Pelt TI (2012) Bering Sea linkages. Deep-Sea Res II 65-70:2-5

Williamson NJ, Traynor JJ (1996) Application of a onedimensional geostatistical procedure to fisheries acoustic surveys of Alaskan pollock. ICES J Mar Sci 53:423-428

Winter A, Swartzman G, Ciannelli L (2005) Early- to latesummer population growth and prey consumption by age-0 pollock (Theragra chalcogramma), in two years of contrasting pollock abundance near the Pribilof Islands, Bering Sea. Fish Oceanogr 14:307-320

Wu J, Loucks OL (1995) From balance of nature to hierarchical patch dynamics: a paradigm shift in ecology. $Q$ Rev Biol 70:439-466

Zeppelin T, Ream R (2006) Foraging habitats based on the diet of female northern fur seals (Callorhinus ursinus) on the Pribilof Islands, Alaska. J Zool (Lond) 270:565-576

Zhang ZQ, Sanderson JP (1993) Spatial scale of aggregation in three acarine predator species with different degrees of polyphagy. Oecologia 96:24-31

Submitted: September 11, 2012; Accepted: February 25, 2013 Proofs received from author(s): May 24, 2013 